\title{
Procesy sądowe monasteru poczajowskiego ze starostą sandomierskim i kasztelanem bielskim Andrzejem Firlejem
}

\author{
ks. archimandryta Andrzej Borkowski \\ Katedra Teologii Prawosławnej, Uniwersytetu w Białymstoku \\ Polska \\ borkowskiunath@yahoo.gr
}

\begin{abstract}
Rev. Andrzej Borkowski, Lawsuits of the Pochayiv Monastery by Starosta of Sandomierz and Castellan of Belz Andrzej Firlej, Elpis, 17 2015: 65-80.

Abstract: The story of the Pochayiv Monastery began with the visit of the greek Metropolitan Neofit to a woman named Anna Gojska at Orla estate, several miles from Pochaev. He gave Anna an icon brought from Constantinople, and it stayed in her private chapel for some 30 years. In 1597 Anna gave the icon to the monastery on the mountain. She also gave lands and money. The monks built a new stone Dormition church to house the icon, for which Anna also gave funds. In 1604, the monastic community was joined by Ivan Zalizo. He received the monastic name of Job and was elected the monastery's hegumen. Job introduced strict discipline and other reforms of monastic life. After Anna died, the mountain on which the monastery lay was inherited by Anna's grandson Andrzej Firlej, governor of Sandomierz and Castellan of Belz, a convert to the Lutheran Church and very opposed to Eastern Orthodoxy. In 1623 Firlej raided the monastery, taking the holy icon and many jewelry. Job was initiated lawsuits of the Pochaiyv Monastery with Castellan of Belz. Thanks his to the efforts the Court of Lublin ordered the return image of what actually occurred. Court decision Andrzej Firlej finally returned the icon to the monks in 1644. Job of Pochayiv died on October 25, 1651.
\end{abstract}

\begin{abstract}
Streszczenie: Historia monasteru poczajowskiego związana jest z wizytą greckiego metropolity Neofita u szlachcianki o imieniu Anna Gojska z Orli, miejscowości położonej kilka mil od Poczajowa. Hierarcha podarował Annie przywiezioną z Konstantynopola ikonę, która została umieszczona w jej prywatnej kaplicy na około 30 lat. W 1597 Anna przekazała ikonę do monasteru na górze poczajowskiej. Podarowała jemu także grunta i fundusze. Dzięki hojnym ofiarom szlachcianki mnisi wznieśli nową kamienną Cerkiew, do której przenieśli ikonę. W 1604 r. do wspólnoty monastycznej dołączył Iwan Zalizo. Otrzymał imię mnisze Hioba i został wybrany igumenem monasteru. Hiob wprowadził surową regułę, dyscyplinę i inne reformy życia monastycznego. Po śmierci Anny, górę, na której był położony monaster odziedziczył wnuk Anny Andrzej Firlej, starosta sandomierski i kasztelan bielski, po konwersji do Kościoła luterańskiego nastawiony nieprzychylnie do prawosławia. W 1623 r. Firlej najechał zbrojnie monaster, rabując cudowną ikonę oraz wiele kosztowności. Hiob był inicjatorem procesów sądowych monasteru poczajowskiego z kasztelan bielski. Dzięki jego staraniom Trybunał Lubelski polecił zwrot wizerunku, co faktycznie nastąpiło. Decyzją sądu Andrzej Firlej ostatecznie zwrócił ikonę mnichom w 1644 r. Hiob Poczajowski zmarł 25 października 1651.
\end{abstract}

Keywords: Pochayiv Monastery, Job of Pochayiv, Andrzej Firlej, lawsuits

Słowa kluczowe: Monaster Poczajowski, Hiob Zalizo, Andrzej Firlej, procesy sądowe

Ostatnie dziesięciolecie działalności św. Hioba upłynęło w uporczywej i nieustannej walce z nieprzejednanym wrogiem monasteru poczajowskiego, Andrzejem Firlejem, zapoczątkowanej wkrótce po jego wyborze na ihumena. Pozwolę sobie zatrzymać się i nieco dokładniej przyjrzeć się powyższym sporom, od których zależały losy i samo istnienie monasteru. $Z$ powagi sytuacji zdawały sobie sprawę obydwie strony. Św. Hiob w swych skargach i protestach niejednokrotnie podkreślał nieszczere zamiary możnowładcy wobec monasteru: „chotieczy toje miestce swiatoje jeho m’ł: Pan Bielzskij (Andrzej Firlej) zniszczyt', z monastyra zakonnikow wykinut', a zatym chwału bożuju zatłumyt"'. Zgodnie z testa-

Державний архів Тернопільської області (dalej: ДАТО), ф. 258 (Почаевский Архив), оп. 3, д. 1168/2: Судебное дело с наследниками Анны Гойской-Фирлеями Марновскими в связи с нарушениями ими завещзания Анны Гойской в пользу монастыря (9. III. - 10. XII. 1641), к. 93. Skarga ihumena poczajowskiego wobec wydanego przez Firleja mentem swej babki Anny Hojskiej, Andrzej Firlej otrzymał w spadku Poczajów, Orlę oraz inne majątki². Jak widać z powyższego zapisu Hojska przywiązywała szczególną uwagę do swego pokrewieństwa $\mathrm{z}$ bogatym i znaczącym rodem Firlejów. Odsuwa od prawa dziedziczenia wszystkich pozostałych krewnych, często bliższych, aby wszystko przekazać „miłym” wnukom Andrzejowi i Iwanowi Firlejom.

Historyk Paprocki wywodzi ród Firlejów od pewnego Niemca, którego zabrał z sobą król Władysław Łokietko z podróży po Niemczech. Po powrocie do Polski nadał mu tytuł stolnika, który pierwotnie funkcjonował pod nazwą

zakazu korzystania z ujścia wodnego (10 grudnia 1641 r.). В. Левицкий, Материалы по истории Почаевской Лавры, t. 1, Почаев 1912, nr 34, s. 66; zob. nr 22, s. 36; $\mathrm{nr} 24$, s. 40; $\mathrm{nr} 42$, s. 92.

2 Zob. В. Левицкий, К вопросу о времени основания Почаевской Лавры и о первоначальной устроительнице ея Анне Гойской, „Волынския Епархиальные Ведомости",1913, nr 11, s. 201-204. 
Firlegiera (niem. vorlegen). W ten sposób stał się protoplastą znamienitego polskiego rodu Firlejów ${ }^{3}$. Ród ten zamieszkiwał pierwotnie $\mathrm{w}$ województwie krakowskim, następnie rozprzestrzenił się w krótkim czasie na Litwie i Rusi Kijowskiej. Ostatecznie swą główną siedzibę założył w Dąbrowicy na Wołyniu. Traczewski charakteryzuje ród Firlejów, jako wyróżniający się statecznością i rzeczowością, płodny $\mathrm{w}$ wybitne jednostki w sferze administracyjnej i dyplomatycznej. Szczególnie znanym pod tym względem był wojewoda krakowski, wielki marszałek koronny Jan Firlej, żyjący w II połowie XVI w. Ród Firlejów wyróżniał się wyjątkowym przywiązaniem do protestantyzmu, którego byli zdeklarowanymi popularyzatorami. Do ich rodowych majątków przybywali kaznodzieje $\mathrm{z}$ całego Zachodu a protestanckie szkoły założone w licznych majątkach, przyciągały swym poziomem erudycji i wyśmienitą organizacją, dzieci nawet najsroższych rodzin rzymskokatolickich. Rodowy majątek Firleja - Lubartów, zamienił się w miasteczko studenckie. Ów znamienity ród wyróżniający się liczebnością swych członków, bogactwem i sławą, poczynając z XVII w. podupada i zanika. Wspomniany Andrzej Firlej, na początku kasztelan bielski następnie starosta sandomierski, umiera bezdzietny pomimo swego ożenku z pannami Dorohostajską i Przemską.

Rodzinne kontakty pomiędzy Firlejami i Hojskimi zawiązały się poprzez ślub kasztelana radomskiego i starosty kowieńskiego Andrzeja Firleja z bratanicą Anny Hojskiej Barbarą Kozińską, po pierwszym mężu księżną Zbarażską. Ów związek dał im dwóch synów, wspomnianych wcześniej Iwana i Andrzeja. Jak widać z licznych zapisów Anna Hojska bardzo lubiła swych wnuków, gdyż często nazywała ich „miłymi”. „Buduczy w letiech swoich podoszłaja” i nie mając sił, ze względu na starość zarządzać swymi obszernymi majątkami, zdecydowała zapisać je w testamencie bliskim sercu wnukom. Dnia 17 maja 1602 r. przybywa osobiście do Głównego Trybunału Lubelskiego aby zapisać w księgach trybynalskich swój testament. Usuwa z niego wszystkich pretendentów do dziedziczenia jej majątkami z wyjątkiem Iwana i Andrzeja Firlejów: „ni na koho inszeho, tylko na dziatki wiel. i.m. pana Andrzeja Firleja z Dombrowici, kasztelana Radoms., Kowielskiego starosty ${ }^{4}$, a wnuczki moie, $\mathrm{z}$ bratanka moiey rodzoney nieboszkiey pani Barbary z Kozina spłodzonych ${ }^{5}$, którym uczyniła zapis na ...imienia swoie, w wojewodztwie Wołynsktm, a Powiecie Krzemienieckim leżące, miasteczko Orlią z Zamkiem, z strzelbą y ze wszelką armatą do obrony przygotowaną, miasteczko Jarofiówkę, wieś Komnatkę, wieś Sawczyce, części imienia w Bereżcach Niznych i Wyznych, Dwor y wieś Poczajow z Boiarami, Ludzmi, Grontami y wszystkiemi Powinnosciami ich, z stawami, młynami, karczma-

\footnotetext{
3 A. Boniecki, Firleje, [w:] Herbarz polski, t. 5, Warszawa 1902, s. 285-295. Zob. Сендулский, Местечко Домбровица, Ровенского уезда, „Волынския Епархиальные Ведомости", 1882, nr 9, s. 235.

4 Kasztelan radomski Andrzej Firlej w niektórych dokumentach nazywany jest starostą kowelskim. Zob. K. Niesiecki, Firlej, [w:] Herbarz Polski, t. 4, Lipsk 1839-1845, s. 37, w którym mówi się, iż trzymał $i$ starostwo Kowelskie. Левицкий, Материалы..., t. 1, nr 1, s. 1; nr 2, s. 3.

5 Левицкий, Материалы..., nr. 1, s. 1.
}

mi, także z stadem, Bydłem wszelkim małym i wielkim z Paszniami Dwornymi w Gumnach złożonemi y na Polach zasianemi, y ze wszystkiemi Pozytkami y Przynalez-

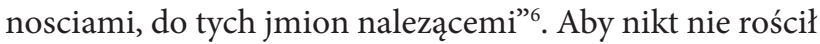
praw do majątku zapisanego jej wnukom, zadośćuczyniła przyrodnim dzieciom Andrzeja Firleja - paniom Mikickiej i Bełzeckiej, przykazując wypłacić im po swej śmierci po 5 tysiecy złotych. Taka sama kwota została wyznaczona rodzonym siostrom Andrzeja i Iwana - Sofii, Annie i Barbarze Firlej, która miała zostać im wypłacona z majątku Anny Hojskiej po wyjściu za mąż. Wniesiony przez Annę Hojską do Trybunału Lubelskiego testament podpisali „wielmozny iego mosc Pan Andrzey Leszczynski z Leszna wojewoda Brzeski Kuiawski starosta Nakielski. Jego mosc Pan Zbigniew Osolinski Podkomorzy Sendomirski Marszałek Trybunalski. Jego mosc Pan Mikołay Czyzewski Chorązy Chełmski. Jego mosc Pan Szczęsny Słupecki, a Jego mosc Pan Piotr Bal Pieczęci swoia przyłożyć y Ręki swoie Podpisac raczyli"' Wraz z testamentem Anny Hojskiej do ksiąg trybunalskich wniesiono zapis kasztelana radomskiego Andrzeja Firleja, którym gwarantuje Hojskiej pośmiertne swobodne korzystanie $\mathrm{z}$ dochodów zapisanych majątków oraz opiekę nad założonym przez nią monasterem poczajowskim oraz cerkwiami prawosławnymi, znajdującymi się w granicach jej posiadłości. Pod groźbą kary w wysokości 10 tysięcy kop litewskich groszy zagwarantował nienaruszalność testamentu, przez siebie, swych synów i potomków

Po upływie 9 lat 24 października 1611 r., Anna Hojska wniosła do ksiąg krzemienieckich drugi zapis, w którym wyrzekała się wszelkich dochodów z majątków na rzecz wnuka Andrzeja Firleja. Pozostawiła sobie jednak prawo nadzoru nad monasterem poczajowskim. Dnia 21 marca 1617 r. w krzemienieckich księgach grodzkich zapisano jej ostatni testament, w którym potwierdziła moc prawną poprzednich zapisów. Zwracała się w nim z prośbą do wnuka Andrzeja, aby pochowano ją według obrządku wschodniego religii greckiej ,według zakonu naszego greckiey wiary", w grobowcu jej męża w monasterze w Dorohobużu. Wszystkie zapisy Anny Hojskiej charakteryzuje szczególna troska, którą otacza cerkwie prawosławne, znajdujące się w jej majątkach oraz monaster poczajowski. Szczególnie czule brzmią słowa jej zapisu, w których zwracała się do Andrzeja Firleja: „a cerkiew moją Orlanską y monastyr Poczaiowski także y inne Cerkwie w tey maiętnosci Orlanskiey bedące, ze wszystkemi Fundacyami tak, iako ode mnie na chwałę Boga Naywyszego założone są, w niczym nienarusznie zachowac według wiary y zakonu Greckiego, Za co i. m ,ci Pan Bog wieczną zapłatą będzie"'.

Do czasu śmierci Anny Hojskiej, Andrzej Firlej nie był częstym gościem w Poczajowie. Większość czasu spędzał za granicą pośród protestanckich nauczycieli, jednak po śmierci fundatorki stał się jego pełnoprawnym właści-

\footnotetext{
Tamże.

Tamże.

Zob. Tamże, nr 1-2, s. 1-5.

Tamże, nr 6, s. 12.
} 
cielem. Z tego momentu rozpoczyna się spór między nim i monasterem poczajowskim, a dokładniej z jego ihumenem Hiobem Zalizo. Gniew i nienawiść Andrzeja Firleja były skierowane, jak widać z przytoczonych aktów, przeciwko „nieprawnemu” przełożonemu monasteru. Narzędziem jego niecnych zamiarów stał się jeden z mnichów Józef Baca, który wraz z mnichem Sylwestrem informował go o poczynaniach ihumena. W zamian za współpracę Andrzej Firlej obiecał mu swe poparcie przy wyborze na ihumena. Wkrótce zamysły Józefa Bacy zostały odkryte przez św. Hioba, który wraz z mnichami Barlaamem Szpraskim i Pawłem Kudrykowiczem wytoczyli przeciwko niemu 13 czerwca 1645 r. sprawę w Sądzie Krzemienieckim ${ }^{10}$.

W 1641 r. Andrzej Firlej wysłał sługę Grzegorza Kozińskiego, który wraz z innymi poddanymi wtargnął do monasteru na Górze Poczajowskiej, rabując utensylia cerkiewne oraz cudowną ikonę Matki Boskiej ${ }^{11}$. Na rozprawie

10 Tamże, nr 72, s. 159. nastyra ubohoho Pocajewskoho z wielu pobożnych dobrodziejów konerowanyj, z jałmużny zakonniczoje prysposoblenyj, z miesca tamocznieho cerkownoho, niewiedat', qo fine, gwałtownie wział i z miestca tamocznieho ruszył. W kotorym to depozycie tyje reczy byli, Naporod: Effines Bohorodicy panny czudami wielikimi znacznymi wsławlenyj kosztownyj, kamienmi dorohimi sażonyj, na kotoryj hrywień try sczyroho zołota $\mathrm{z}$ smielcem pereł urianskich wielikich kop osmnadcet', Kryżykow Aspisowych try, zołotych kryżykow dwa, Manelj sczyrozłotych par dwie, pierstieńkow sczyrozłotych siem, także i łancuch sczyrozłotyj około obrazu. Apparaty cerkownyje, tak od zoszłoje panieje sudinoje, jako i inszych roznych ludiej pobożnych nadanyje roznyje Gatunku bławatnyje, a mienowicie ryz troje: odni Aksamitnyje czornyje zołotom i perłami haftowanyje, druhije Atłasowyje błakitnyj, Trecije Adamaszkowyje zielenyje. Stycharow dyjakonskich dwa: odien Atłasowyj błakitnyj, druhij niendzowyj Pstryj; stycharow połotna Kolenskoho dwa Jedwabom szytych; Pasow Jedwabnienych dwa, Patrachielów dwa: odien czornyj aksamitnyj zołotom i perłami haftowanyj, druhij Adamaszkowyj zielenyj; wozduchow par dwie: aksamitnych para haftowanych zołotom i perłami, a para Atłasowych błakitnych. Narakwic par dwie: odni Aksamitnyje czornyje zołotom i perłami haftowanyje, druhyje Adamaszkowyje zielenyje; orar dyjakonskij, Aksamitnyj roznym zołotom i perłami haftowanyj; zawiesow dwa Adamaszkowych czerwonych. Jewanhelia Aksamitom krytaja, srebrom oprawnaja złocistaja. Kryż srebrnyj złocistyj z patynoju łożkoju i zwiezdoju, także kadilnica srebrnaja i lichtarow dwa srebrnych. Kotoryje to reczy wyszmienowanyje od fundatorki toho Monastyra nadanyje byli. Potym kotoryje knieżata ich miłostiech: Michał i Adam Witniewskije i knieżna Jeje miłosti: Marusza Zbarazkaja konferowali, to jest':ryz dwoje: odniAksamitnyje zielenyje, druhije telitowyje biełyje; stychar dyjakonskij, Atłasowyj celistyj i Patrachiel tojeż masti. Kielich srebrnyj złocistyj, kamienmi dorohimi sażonyj; kadilnica srebrnaja; lichtar srebrnyj wielikij; tablica srebrnaja wielikaja złocistaja; Jewanhelije moskowskije, blachami srebrnymi miesto diech oprawnyje; miska srebrnaja moskowskaja, także lichtarow dwa srebrnych; ryzy Aksamitnyje czerwonyje, zołotom i perłami haftowanyje; stichar dyjakonskij, Aksamitnyj wiszniewyj, także haftowanyj. Wozduchow dwa Aksamitnych wielikich, perłami i zołotom haftowanyje; Patrachil i orar dyjakonskij także haftowanyj;płaszczenica Atłasowaja biełaja, wkoło zołoto i perłami haftowanaja i kamienmi dorohimi sażona; tablica srebrnaja wielikaja łoktiewaja. Tak że od jeje miłosti: panieje Matfiejewoje Malińskoje ryzy Atłasowyje czerwonyje; stychar papufastj kitajkowyj; Jewanhelia srebrom oprawnaja, lichtar srebrnyj, zawiesow dwa zielenych Adamaszkowych. Od jeje miłosti: panieje Tychonowoje Szaszkiewiczowoje - ryzy Atłasowyje wiszniewyje; stichar dyjakonskij Adamaszkowyj czerwonyj; petrachil, wozduchow dwa, orar tak że Atłasowyje; tablica srebrnaja. Od jeje miłosti: panieje Hrynickoje łowczynoje wołynskoje ryzy Adamaszkowyje karmazynowyje czerwonyje; stychar tojeż masti; maneli sczyrozłotyje; Hrobnica, abo puszka do schowania Sakramentu srebrnaja. Do toho prez samych zakonnikow sprawlenyje, to jest': ryz dwoje, odni Adamaszkowyje biełyje, druhije tabinowyje czornyje; sti- sądowej z 5 września 1644 r. Andrzej Firlej usprawiedliwiał się ze swego postępku twierdząc, że nie zabrał tych rzeczy siłą, ale za zgoda ihumena „według zwyczaju dawnego”, ze względu na grożące niebezpieczeństwo ze strony częstych najazdów tatarskich oraz niedostateczną troskę poprzednich ihumenów, wskutek czego przepadło wiele cennych przedmiotów ${ }^{12}$. Pomimo częstych próśb mnichów zrabowane cenności nie powróciły do pierwotnego właściciela ale posłużyły za przedmiot codziennego użytku w zamku Andrzeja Firleja w Kozinie ${ }^{13}$. Szkody poniesione przez monaster poczajowski oszacowano na 20 tysięcy złotych.

Zgodnie z darowizną Anny Hojskiej z 14 listopada 1597 r., jej sukcesorzy zostali zobowiązani do wypłacania corocznie z majątku orlańskiego 30 kop litewskich groszy na utrzymanie monasteru, znajdującej się w nim cerkwi i mnichów: „na opatrenie toje cerkwi i monastyra i czerncow"14. Pomimo to monaster poczajowski mósiał cierpliwie znosić wszystkie krzywdy, nie mając sił aby walczyć z możnym magnatem, który w tym czasie zajmował funkcję kasztelana bielskiego a następnie starosty sandomierskiego (na podobieństwo swego ojca, który na początku był kasztelanem radomskim a następnie starostą kowieńskim). Stanowisko kasztelana, senatora oraz bliskiego współpracownika wojewody cieszyło sie wysokim autorytetem wśród szlachty. Posiadał prawo przewodniczenia w sejmach powiatowych, czasami w swej osobie reprezentował rożne funkcje, od organizatora pospolitego ruszenia do przewodniczącego komisji sądowych, rozpatrujących apelacje od postanowień powiatowych sądów podkomorskich ${ }^{15}$.

char dyjakonskij kitajkowyj, lazurowyj; Patracheliow Adamaszkowych błakitnych dwa; zawiesow kitajkowych zielenych try; Towalen jedwabom szytych szest; także chustok szytych jedwabom szest, bawołnic try. I inszych niemało reczej, do obradkow cerkownych i celebrowania prenadostojniejszoje ofiery Bohu litorhijej swiatoj należaczych, z skrynieju to wsie wziawszy, do zamku swojeho kozinskoho odprowadił i to wsie pry siebie trymajet..... ДАТО, ф. 258, оп. 3, д. 1168/2, к. 21 - 22. Odpis z ksiąg grodzkich krzemienieckich zawierający skargę ihumena Poczajowskiego Hioba Zelezo na kasztelana bielskiego Andrzeja Firleja za nasłanie na monaster Grzegorza Kozińskiego w celu zagarnięcia cudownej ikony Matki Boskiej Poczajowskiej oraz jego majątku z dnia 7 września 1641 r. Левицкий, Материалы..., nr 26, s. 44 - 45.

12 ДАТО, ф. 258, оп. 3, д. 1169: Выспись из городских Кременеиких актовых книг (1642 - 44), к. 217 - 39. Dekret sędzi treciejskiego w sprawie rozpatrzenia skarg monasteru poczajowskiego przeciwko Andrzejowi Firlejowi z 5 września 1644 r. Левицкий, Материаль..., nr. 64, s. 142.

13 W skardze wniesionej 7 września $1641 \mathrm{r}$. do Sądu Krzemienieckiego św. Hiob pisze, że Andrzej Firlej „... i inszych nie mało reczej, do obradkow cerkownych i celebrowania prenadostojniejszoje ofiery Bohu litorhijej swiatoj należaczych, z skrynieju to wsie wziawszy, do zamku swojeho Kozinskoho odprowadił i to wsie pry siebie trymajet, a czasto krot buduczy pryjatielsko rekwizytus, aby im to do celebrowania restu prywiernuł i oddał, prywiernut' nie choczet i na swój pożytok toje oboroczajet". Zob. ДАТО, ф. 258, оп. 3, д. 1168/2, к. 22. Odpis z ksiąg grodzkich krzemienieckich zawierający skargę ihumena Poczajowskiego Hioba Zelezo przeciwko kasztelanowi bielskiemu Andrzejowi Firlejowi za nasłanie na monaster Grzegorza Kozińskiego w celu zagarnięcia cudownej ikony Matki Boskiej Poczajowskiej oraz jego majątku z dnia 7 września 1641 r. Левицкий, Материалы..., nr. 26, s, 45.

14 ДАТО, ф. 258, оп. 3, д. 1168/2, к. 38 - 39; Левицкий, Материалы..., nr. 30, s. 53.

15 И. И. Лаппо, Великое Княжество Литовское за время от заключения Люблинской Унии до смерти Стефана Батория (1569-1586) : опыт исследования политического и общественного строя, t. 1, С.- 
Czy monaster był $\mathrm{w}$ stanie walczyć o swoje prawa z wpływowym magnatem, będącym na dodatek jego kolatorem? Należy zauważyć, że owe czasy były okresem największego tryumfu rzymskiego katolicyzmu i jednocześnie najdotkliwszym jarzmem prawosławia w Rzeczypospolitej. Czasy rządów Zygmunta III - wychowanka jezuitów, twórcy niekanonicznej unii kościelnej w Brześciu, odbiły się żałosnym echem na kartach historii obojga narodów oraz Kościoła prawosławnego, będącego wówczas religią nierówno uprawnioną. Jego świątynie przekazywano $\mathrm{w}$ ręce unitów a prawosławnych biskupów (wyświęconych przez patriarchę jerozolimskiego Teofana w 1620 - 1621 r.) skazano na banicję. Zadziwiającym jest sposób, w jaki monaster w Poczajowie w tak trudnych godzinach zdołał zachować w swych ścianach prawosławie. W czasach, kiedy liczne monastery na Wołyniu: Św. Spasa i Podniesienia Krzyża Pańskiego w Dubnie, Św. Trójcy w Dermaniu, Żydyczeński i inne przechodziły na unię ${ }^{16}$. Główna zasługa znajduje się po stronie dwóch postaci: fundatorki Anny Hojskiej oraz igumena poczajowskiego św. Hioba Zalizo.

W tym trudnym dla monasteru okresie nie mógł okazać swej pomocy biskup łucki Izaak Boryskowicz, wyświęcony w $1621 \mathrm{r}$. przez, patriarchę jerozolimskiego Teofana ${ }^{17}$. Nie wyróżniał się aktywną działalnością ani silną osobowością nieodzowną $\mathrm{w}$ walce $\mathrm{z}$ unią. Prześladowany przez unickiego biskupa łuckiego Jeremiasza Poczapowskiego porzuca Łuck, przenosząc się na stałe do Kijowa. Nie zrywa swych kontaktów z wiernymi, wizytując niejednokrotnie parafie znajdujące się na terenie jego diecezji. Jednak sam fakt nieobecności arcypasterza był dotkliwie odczuwany przez wiernych. W 1632 r. porzuca katedrę w Łucku, osiadając w Lawrze Kijewo - Peczerskiej (zachował godność ordynariusza diecezji aż do śmierci w 1640 r.). W tym czasie nieoficjalnie biskupem pińskim był Grek Abraham ${ }^{18}$.

Петербург 1901, s. 616 - 635. Z. Góralski, Urzędy i godności w dawnej Polsce, Warszawa 1983, s. 137-139.

16 М. Щеглов, Историческая записка о Дубенской Крестовоздвиженской пустыни, „Волынския Епархиальные Ведомости”, 1884, nr 23 - 25, s. 20; А. Малевич, Древняя Жыдычинская архимандрия на Волыни, Почаев 1905, s. 192; П.Н. Батюшков, Волынь. Исторические судьбы Юго-Западного края, СПб. 1888, s. 156. A. Borkowski, Początki monastycyzmu wolyńskiego, „Cerkovnyj Vestnik”, 2014, nr 4, s. 30-63.

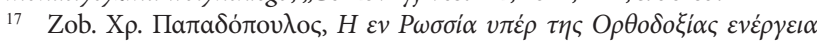

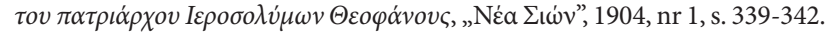
Макарий (Булгаков), митр. История Русской Церкви, t. 6, Москва 1996 s. 401-404. П.И. Орловский, Участие запорожских казаков в восстановлении Иерусалимским патриархом Феобаном православной Западно-русской церковной иерархии в 1620 году и Киевский церковньй собор 1629 года, „Киевская Старина”, 1905, nr 10, s. 133-141. К. Сhodynicki, Kościót prawosławny a Rzeczypospolita polska. Zarys historyczny 1370 - 1632, Warszawa 1934, s. 427-428. М. С. Грушевський, Iсторія України-Руси, t. 7, Київ 1995, s. 426-437. А. Mironowicz, The Activities of the Patriarch Teofanes III in the Polish-Lithuanian Commonwealth, [w:] The Orthodox Church in the Balkans and Poland. Connections and Common Tradition, Białystok 2007, s. 81-82. T. Hodyna, Między królem a carem. Moskwa w oczach prawosławnych Rusinów - obywateli Rzeczypospolitej (na podstawie piśmiennictwa końca XVI - połowy XVII stulecia, Kraków 2008, s. 65-72. A. Borkowski, Patriarchaty Wschodu w dziajach Rzeczypospolitej (1583-1601), Białystok 2014, s. 215-218.

18 В. Иванов, Епископы древней Луцкой епархии, Почаев 1891, s. 88 - 94; L. Adamczuk i A. Mironowicz, Duchowieństwo prawosławne w X-XVIII wieku, [w:] Kościót prawosławny w Polsce. Dawniej i dziś, Warszawa 1993, s. $75-83$.
Monaster w Poczajowie, znajdujący się w tak trudnych okolicznościach w swych krzywdach mógł jedynie uzbroić się w cierpliwość, oczekując bardziej sprzyjających czasów. Ów moment nastąpił wraz z wstąpieniem na tron Władysława IV. Ożyły nadzieje prawosławnych wiernych na pomyślne uregulowanie statusu prawnego ich Kościoła. Sejm elekcyjny przyniósł istotne zmiany w położeniu Kościoła greckiego w Rzeczypospolitej a co najważniejsze, przywrócił jego równouprawnienie z Kościołem unickim. Król, kierując się interesami państwa wydał 14 marca 1633 r. dekret, którym zagwarantował wiernym Kościoła prawosławnego: prawne uznanie hierarchii; potwierdzenie prawa do posiadania świątyń, szkół i drukarni; zapewnienie o wysłaniu komisji w celu dokonania podziału cerkwi i monasterów w miastach królewskich, proporcjonalnie do liczby wyznawców; całkowitą wolność kultu ${ }^{19}$. Ogólny nastrój radości i nadziei na lepszą przyszłość, który ogarnął prawosławnych nie był obcy społeczności monasteru poczajowskiego a w szczególności św. Hiobowi. Po okresie cierpliwych wyczekiwań monaster rozpoczyna śmiałe i zdecydowane działania na rzecz obrony swych praw w sądach grodzkich, ziemskich i trybunalskich.

Dnia 9 marca 1641 r. Św. Hiob osobiście przybył do Sądu Grodzkiego w Łucku, aby złożyć w imieniu braci monasteru następującą skargę: „kasztelan bielski Andrzej Firlej, nie biorąc pod uwagę postanowień zawartych w testamencie Anny Hojskiej oraz wyraźnego zakazu prześladowania i pustoszenia świętego miejsca, zamiast ochraniać i bronić znajdującuch się w monasterze duchownych i poddanych a także nadanych mu w zapisie pól i cerkiewnego majątku przed niesprawiedliwymi zarzutami i szykanami, ze wszystkich sił stara się zbezcześcić święte miejsce i wygnać stąd mnichów. Z jego rozkazu zabrano $\mathrm{z}$ monasteru ikonę Przenajświętszej Bogarodzicy a następnie przekazano do Zamku Kozińskiego, wsławionej licznymi cudami i obsypanej szlachetnymi kamieniami. Zrabował szaty liturgiczne, podarowane przez fundatorkę, licznych ofiarodawców oraz zakupione przez mnichów. Nakazał odesłać do swego zamku dwie srebrne kadzielnice, dwa krzyże, kielichy wraz z patenami oraz pozostałe naczynia liturgiczne (wszystkie wykonane ze złota i srebra), nieodzowne przy celebrowaniu Św. Liturgii. Korzystając z usług swych poddanych poczajowskich zniszczył znaki wyznaczające granice ziem monasterskich. Przyswoił sobie ziemie orne, las przy cerkwi, błonia i łąki. Pomimo częstych upomnień ze strony monasteru, zaprzestał wypłacać przyznanej mu w testamencie sumy. Podczas celebrowanych z okazji uroczystych świąt nabożeństw, zezwolił na otwieranie szynków na terenie monasteru. Pogardzając jakimkolwiek prawem i ładem społecznym 19 czerwca 1640 r. wysłał swego pachołka poczajowskiego wraz z gromadą ciżby (w liczbie kilkudziesięciu), którzy napadli na grunta monasterskie, zniszczyli ogrodzenie okalające ogrody poddanych monasteru a z zajętych pól przegnali mnichów. Takie postępowanie Firleja naraziło monaster na znaczne straty, wobec

19 A. Mironowicz, Kościół prawosławny w dziejach dawnej Rzeczypospolitej, Białystok 2001, s. 103. 
czego zwraca się z prośbą o wniesienie do ksiąg grodzkich oskarżenia przeciwko niemu"(tłum. własne) ${ }^{20}$.

W celu potwierdzenia prawdziwości zeznania, złożonego przez św. Hioba w Sądzie Łuckim, wezwano woźnego generała Stanisława Poroszkiewicza, który „majuczy pry sobie szlachty ludiej dobrych” ( Mikołaja Piaseckiego i Piotra Talalaja) zbadał sprawę i potwierdził zgodność zeznania św. Hioba w Sądzie Grodzkim w Krzemieńcu ${ }^{21}$.

Skarga wniesiona przez świętego do Sądu Łuckiego oraz relacja woźnego przed Sądem Krzemienieckim jeszcze bardziej rozjątrzyły Andrzeja Firleja, który postanowił ostatecznie roprawić się z monasterem poczajowskim. W niedzielę 14 lipca $1641 \mathrm{r}$., gdy w świątyni celebrowano nabożeństwo, nasłał na monaster swego starostę orlańskiego Bryskiego i dozorcę poczajowskiego Kamieńskiego gromadą jeźdźców i chłopstwa zebranego z włości orlańskich (do kilkuset osób). Uzbrojeni w strzelby, kosy i cepy napadli na monaster i otworzyli ogień, znieważając przy tym obelżywymi słowami mnichów, święte miejsce a nawet Przenajświętszą Bogurodzicę ${ }^{22}$. Następnie weszli na pola monasterskie, zdeptali i skosili zboże (400 kop pszenicy, 500 żyta i 300 jęczmienia), rozrzucili bądź spalili kilkaset stogów siana. Tylko w wyniku zniszczenia zbóż monaster poniósł straty w wysokości 3 tys. kop litewskich groszy. Gdy z monasteru wyszło dwóch mnichów: przełożony Filoteusz Borysowicz i diakon Hilarion, aby uspokoić rozgorzały tłum, zostali pobici i wyśmiani. Jeden z uczestników schwycił muszkiet i uderzył nim w bok przełożonego, inny najechał koniem i zwalił go $\mathrm{z}$ nóg. W tym momencie tłum pospólstwa rzucił się na niego, nanosząc mu dotkliwe rany. Dozorca Poczajowski Iwan uderzył obuchem w lewą rękę diakona Hilariona, a następnie zaczął bić go po szyi, „potom piast'ju piastuj szyju potruczał”. Niemiłosiernie pobitych zabrano i przewieziono wozami do monasteru. Na żądanie św. Hioba, następnego dnia - 15 lipca, przybyli do monasteru: woźny generał Stanisław Poroszkiewicz z dwoma szlachcicami Maciejem Lesiewiczem i Iwanem Stradomskim, którzy

\footnotetext{
20 ДАТО, ф. 258, оп. 3, д. 1168/2, к. 4-5. Protestacja św. Hioba w obliczu jawnej grabieży majątku monasterskiego wraz z cudowną ikoną Matki Boskiej Poczajowskiej przez kasztelana bielskiego Andrzeja Firleja z dnia 9 marca 1641 r. Левицкий, Материалью.., nr 22, s. 36 - 37.

21 ДАТО, ф. 258, оп. 3, д. 1168/2, к. 6. Oświadczenie woźnego Stanisława Poroszkiewicza o krzywdach naniesionych przez Andrzeja Firleja monasterowi poczajowskiemu. Левицкий, Материаль..., nr 22, s. 38 - 39.

22 W skardze złożonej przez św. Hioba do Ksiąg Krzemienieckich czytamy: „Tiepier swieżo dnia czetyrnadcatoho, M'ca ijula, roku tiepieresznieho tysiecza szestsot czotyrdziesiat pierwoho, w dień niedielnyj, gdy protestujuczyje nabożeństwo nabożeństwo cerkwi pry służbi bożoj otprawowali, pod takij czas Jeho mł': Pan Bielzskij, nasławszy starostu swojego orleńskoho Bryskoho i dwornika poczajewskaho Kamienskaho z kupoju ludiej roznych służalczych daraganow i poddanych swoich, zo wsieje wołosti do Orlei należaczych, z strelboju, kosami, cepami i inszym orużjem, do kilko sot człowieka, Jeho mł’: samomu nazwiskami nazwiskami imionami wiedomymi, Kotoryje, wproś prypadszy pod monastyr strelańje i wołańje uczynili, słowami nieuctiwymi karczemnymi, a raczy wiestce swietoje i zakonnikow także i naswietszuju Pannu nikotoryje z nich innowiercy bluznili”. ДАТО, ф. 258, оп. 3, д. 1168/2, к. 14 - 15. Skarga św. Hioba skierowana przeciwko Andrzejowi Firlejowi za pobicie mnicha Filoteusza Borysowicza i diakona Hilariona oraz zniszczenie zasiewów na polach monasterskich. Левицкий, Материальљ..., nr 24, s. 40.
}

dokładnie zbadali sprawę, poczym wnieśli swe sprawozdanie do Sądu Grodzkiego w Krzemieńcu ${ }^{23}$.

Dnia 7 września 1641 r. św. Hiob wniósł jeszcze dwie inne skargi na Andrzeja Firleja. Pierwsza z nich z dnia 17 lipca $z$ powodu nieprawnego przywłaszczenia ziem monasterskich. Dozorca Poczajowski Kamieński z grupą strzelców, kozaków i czeladzi (w liczbie kilkuset), uzbrojonych w szable, topory kosy i inną broń napadł na pola monasterskie, wygnał z nich mnichów zastępując uzbrojonymi poddanymi i leśnikami. Ów fakt został poręczony przed Sądem Krzemienieckim relacją woźnego generała Stanisława Poroszkiewicza $^{24}$. Druga skarga dotyczyła grabieży utensylii kościelnych z $1623 \mathrm{r}^{25} \mathrm{~W}$ rezultacie złożonych przez monaster skarg woźny generał Stanisław Poroszkiewicz przekazał Andrzejowi Firlejowi cztery pozwy do Sądu w Krzemieńcu. Dnia 25 września, w towarzystwie dwóch szlachciców Iwana Skoryszewskiego i Jakuba Lewackiego, udał się do Poczajowa, aby osobiście doręczyć je tamtejszemu dozorcy Karczewskiemu. Pierwszy pozew zawierał skargę mnichów poczajowskich przeciwko Andrzejowi Firlejowi za przywłaszczenie pól monasterskich; drugi, żądał ich zwrotu, z wynagrodzeniem poniesionych szkód; trzeci, dotyczył niewypłacenia corocznej pieniężnej dziesięciny, zapisanej w testamencie Anny Hojskiej, po 30 kop litewskich groszy, a także zwrocie procentu z powyższej kwoty; czwarty, w imieniu przełożonego Filoteusza Borysowicza i diakona Hilariona, wzywał na sąd braci Pietkiewiczów oraz dozorcę Iwana, oskarżonych o pobicie wspomnianych mnichów. Woźny wyznaczył datę stawienia się obydwu stron przed Sądem Grodzkim w Krzemieńcu na 24 października 1641 r. ${ }^{26} \mathrm{~W}$ wyznaczonym terminie do Sądu Krzemienieckiego przybył św. Hiob, a ze strony Andrzeja Firleja jego pełnomocnik Daniel Grudnicki. Po krótkiej relacji obydwu stron w sprawie napadu na pola monasterskie oraz zniszczenia zbóż, sąd postanowił, aby: w obliczu faktu, iż oskarżenie strony powodowej nie zgadza się z przedstawionymi oskarżeniami, uwolnić czasowo pozwanego od tej sprawy, mnisi natomiast mają prawo ponownie go zasądzić ${ }^{27}$. W sprawie niewypłacenia monasterowi corocznej sumy 30 kop litewskich groszy sąd postanowił, aby pozwany wypłacił ją za okres 12 lat, w przeciwnym razie zostanie poddany karze w wysokości 3 grzywien na rzecz sądu, ponadto zostanie wypowiedziana przez woźnego Wojciecha Rybińskiego banicja, a majątek będzie poddany egzekucji, bądź konfiska$\mathrm{cie}^{28}$. Upełnomocniony Firlej złożył apelację do Sądu Głównego przeciwko postanowieniu Sądu Krzemienieckiego.

\footnotetext{
23 ДАТО, ф. 258, оп. 3, д. 1168/2, к. 14 - 16.

24 Tamże, к. 21 - 22. Skarga ihumena poczajowskiego poręczona przed Sądem Krzemienieckim relacją woźnego Stanisława Poroszkiewicza o zagarnięciu przez Firleja pól monasterskich.

25 Tamże, к. 23 - 24. Sprawa zagarnięcia cudownej ikony oraz utensylii kościelnych.

26 Tamże, к. 27. Odpis z Ksiąg Krzemienieckich zawierający relację Stanisława Poroszkiewicza o wręczeniu przez niego Andrzejowi Firlejowi czterech pozwów. Левицкий, Материальı..., nr 28, s. 48 - 49.

27 ДАТО, ф. 258, оп. 3, д. 1168/2, к. 38 - 39. Odpis z grodzkich ksiąg krzemienieckich o wyznaczeniu ponownego terminu rozprawy w sprawie napadu na pola monasterskie oraz zniszczenia zbóż. Левицкий, Материалы..., nr 29, s. 49 - 51

28 ДАТО, ф. 258, оп. 3, д. 1168/2, к. 34 - 37. Apelacja pełnomocnika
} 
Niecały miesiąc później, 20 listopada w Sądzie Krzemienieckim rozpatrywano sprawę zrabowanych przez Firleja utynsylii kościelnych, cudownej ikony Matki Boskiej oraz odebranych monasterowi majątków ziemskich, zapisanych przez fundatorkę. Po przeczytaniu aktu oskarżenia, adwokat Andrzeja Firleja Daniel Grudnicki oświadczył, że pozwany sądu nie może odnieść uszczerbku w tej sprawie, a zmyśloną krzywdę, którą jakoby naniósł monasterowi powinien rozpatrywać nie sąd ziemski a grodzki, na co strona powodowa wyraziła sprzeciw twierdząc, że Sąd Ziemski jest właściwą instytucją, gdzie mogą być rozpatrywane różne sprawy jak ta, o zwrocie majątku ziemskiego. Sąd Ziemski w Krzemieńcu wysłuchawszy relacji obydwu stron nakazał oskarżonemu, aby nie uchylał się od dalszego rozpatrywania sprawy. W powyższej sytuacji pełnomocnik Firleja wniósł apelację wobec postanowienia sądu do Głównego Trybunału Lubelskiego. Sąd nie dopuścił powyższej apelacji. Wówczas oskarżony złożył protest przeciwko stronniczości i uciskom ze strony sądu, na co sąd odpowiedział, że postępuje zgodnie z prawem.

W dalszym ciągu rozprawy pełnomocnik oskarżonego zgłosił nieprawomocność strony powodowej, tj. św. Hioba na podstawie, iż nie otrzymał inwestytury od biskupa. $\mathrm{Z}$ tego względu ani on, ani pozostali mnisi nie mogą prowadzić żadnej sprawy bez aprobaty biskupa (w typ przypadku biskupa łuckiego). Należy zauważyć, że ów argument będzie wysuwany przez oskarżonego we wszystkich jego procesach $\mathrm{z}$ monasterem. Jednak sąd będzie zawsze potwierdzał wiarygodność piastowanego przez świętego stanowiska. Ten sam argument został wysunięty tego samego dnia w sprawie przywłaszczenia ziem monasterskich. Usiłując dowieść nieprawności i nieprawomocności strony powodowej Daniel Grudnicki oświadczył, że obecny przełożony nie jest wiarygodnym przedstawicielem monasteru, gdyż nie jest w stanie udowodnić, że został mianowany na to stanowisko przez dziedzica. Wobec braku pełnoprawnego igumena i pod nieobecność biskupa pozostali mnisi nie mogą prowadzić tej sprawy. W odpowiedzi na powyższy zarzut św. Hiob słusznie zauważył, że w Kościele rzymskokatolickim przeor lub proboszcz posiada prawo prowadzenia sprawy bez uczestnictwa biskupa. Tak samo igumen, posiadając władzę zarządzania monasterem, może wnosić sprawy do sądu z powodu jakiejkolwiek wyrządzonej monasterowi krzywdy. Biskup prawosławny posiadający swą kapitułę składającą się z białego duchowieństwa nie wtrąca się $\mathrm{w}$ sprawy monasterskie, podobnie $\mathrm{w}$ danym przypadku jego obecność nie jest konieczna ${ }^{29}$.

Zgodnie $\mathrm{z}$ postanowieniem Sądu W Krzemieńcu w sprawie grabieży ziem monasterskich ustalono, aby zbadać sprawę na miejscu wyznaczając termin spotkania na 12 grudnia $1641 \mathrm{r}$. Jednak na krótko przed ustaloną datą

Andrzeja Firleja Daniela Grudnickiego do Trybunału Lubelskiego z 31 października 1641 r. Левицкий, Материаль..., nr 30, s. 51 - 55.

29 ДАТО, ф. 258, оп. 3, д. 1168/2, к. 50 - 90. Odpisy apelacji z grodzkich ksiąg krzemienieckich pełnomocnika Andrzeja Firleja Daniela Grudnickiego wobec postanowień Sądu Ziemskiego w Krzemieńcu i skierowaniu sprawy do Trybunału Lubelskiego. Левицкий, Материаль..., nr 31-32, s. $58-63$. spotkania w dniu 9 grudnia woźny Stanisław Poroszkiewicz z dwoma szlachcicami: Maciejem Lesiewiczem i Dymitrem Mądryckim przybyli do Poczajowa, aby powiadomić zarówno Andrzeja Firleja, jak św. Hioba, iż „dla uważnych pryczyn" śledztwo na ziemiach spornych zostaje przełożone na 14 stycznia $1642 \mathrm{r}^{30}$.

Nawet $\mathrm{w}$ okresie poprzedzającym dochodzenie sądowe Firlej nie zaniechał wyrządzania przeróżnych krzywd monasterowi poczajowskiemu. Korzystając z okoliczności, iż ze względu na swe położenie na szczycie góry monaster posiadał utrudniony dostęp do źródeł wodnych i był zmuszony dostarczać ją z ujść znajdujących się w sąsiedniej wsi - obecnie Starym Poczajowie, Firlej zabronił mnichom pobierania $z$ nich wody. Podczas gdy dwaj mnisi Joachim i Samuel przyjechali po wodę, Firlej ujrzawszy ich nakazał swemu staroście Galenzowskiemu przegnać mnichów. Zebrawszy kozaków i czeladź napadł na nich, porozbijał beczki, a samych mnichów ścigał aż do monasteru, obsypując po drodze obelgami i groźbami. Po powrocie postawił u ujść wodnych straże, mnisi natomiast zmuszeni byli do jeżdżenia po wodę do oddalonej wsi Łosiatyń. Prawdopodobnie wówczas św. Hiob zdecydował się, nie zważając na niezwykłe trudności, wykopać w monasterze studnię, istniejącą do czasów obecnych. Wezwany Woźny Stanisław Poroszkiewicz wraz z dwoma szlachcicami Jakubem Poździckim i Antonim Poździckim 27 listopada 1641 r. w swej relacji potwierdzili wyrządzone szkody - zdruzgotane wozy i pobite beczki ${ }^{31}$.

Andrzej Firlej usposabiał nieprzychylnie poddanych i czeladź do mnichów, od tej pory stale narażonych na szyderstwa, obelgi, pobicia. W dniu Opieki NMP w 1644 r. jeden z mnichów Barlaam Szpraski był wysłany przez św. Hioba do sąsiedniej wsi Ledochów. W drodze powrotnej przejeżdżał obok karczmy poczajowskiej. W tym czasie poddani Firleja: Ignat Iwonicz - leśnik i Kondrat - pastuch, zastąpiwszy drogę dotkliwie go pobili. Wspomniany woźny Stanisław Poroszkiewicz, wezwany przez św. Hioba w asyście dwóch szlachciców Iwana Fluzskiego i Jakuba Kotowskiego 12 października do Poczajowa swą relacją potwierdził, iż „jezdił do Monastyra Poczajewskoho, tamże w celi

30 ДАТО, ф. 258, оп. 3, д. 1168/2, к. 91. Decyzja Sądu Grodzkiego w Krzemieńcu o przełożeniu dochodzenia sądowego na gruntach monasterskich na 14 stycznia 1642 r. Левицкий, Материаль..., nr 33, s. 65.

31 ДАТО, ф. 258, оп. 3, д. 1168/2, к. 93 - 94. Skarga ihumena poczajowskiego wobec zakazu Andrzeja Firleja z korzystania przez mnichów z ujść wodnych. Левицкий, Материалью.., nr 34, s. 66 - 68; W sprawie zakazu Firleja korzystania ze Staro - poczajowskich ujść wodnych dowiadujemy się z aktu oskarżenia św. Hioba, który opisuje ów fakt w sposób następujący: „napadłszy gwałtom, tyje posłancy jeho m’ł, wozy porąbali, boczki porozbijali i samych zakonnikow z rozkazania jeho m’ł, aż pod monastyr honiaczy soromotili, zagroziwszy, żeby nichto z monastyra znieważył się s toje krynicy wody zażywat, zaczym protestantes baczaczy krynicu dobre wartoju opatrenuju, nie ważajuczysie tam bywat, ale nie mał za milu do Łosiatynia i do inszych sieł okolicznych po wodu posyłajut, wielikij niedostatek w wareniu jest i napoju zwyczajnym odnosiaczy tierpiat, gdyby nie inszyje dobrodzieje opatrywali ubogich zakonnikow, znałby prytom miescu bez wody znajdujuczysie emirat myseli, i nie tylko pod tot czas tych, ale częstokrotnie inszych zakonnikow, gdie kolwiek potkawszy słuhi i poddanyje jeho m'ł znieważajut i soromotiat, a szto bolszaja, i dorobi zwyczajnyje, gdy się trafit iti albo jenot prez sieło, z rozkazania jeho m’ł zaboroniajut, groziaczy kijewoju niemoczju", s. 67. 
widził pomienienoho otca Szpraskoho na posieli lieżaczoho, barzo horoho, u kotoroj na ruce prawoj i po pleczach, po chrybtie i poroznych miestcach tieła jeho nie mało ran bitych sinich krywawych klewych, borodu wyrwanuju ohledal"32.

Wyrządzając monasterowi możliwe krzywdy i przykrości, Andrzej Firlej usiłował przed sądem zniesławić i oczernić monaster, a w szczególności jego ihumena. Jednym ze sposobów utrudniania życia mnichom poczajowski było prawo zezwalające na handel we święta alkoholem pod samym monasterem oraz na otwieranie szynków. Św. Hiob niejednokrotnie wnosił w tej sprawie skargi do sądu, na co Firlej 14 lipca 1644 r. wniósł przez woźnego Pawła Żygało do Sądu w Krzemieńcu skargę przeciwko św. Hiobowi, który jakoby zezwolił w monasterze poczajowskim na otwarcie szynków z najrozmaitszymi trunkami: wódką, miodem pitnym, piwem i innymi. Owe szynki, wg relacji oskarżyciela, zostały otworzone przez niego na monasterskim folwarku i u niektórych monasterskich wieśniaków jak np. u Stefana Danca, za co pobierał wiadomą opłatę. Woźny Paweł Żygało wnosząc powyższe oskarżenie do Sądu w Krzemieńcu zeznał, że podczas swego pobytu w Poczajowie był naocznym świadkiem powyższego stanu rzeczy ${ }^{33}$. W rzeczywistości nie były to szynki, a pomieszczenia dla przybywających do monasteru pielgrzymów. Ze względu na jego położenie daleko poza wsią, pośród lasu, mnisi w trosce o przybywających wybudowali dom gościnny, określony przez Firleja mianem szynków.

Ten sam woźny Paweł Żygało 10 listopada $1644 \mathrm{r}$. w imieniu Andrzeja Firleja wniósł do Sądu w Krzemieńcu inną skargę na mnichów z monasteru poczajowskiego: przełożonego Filoteusza Borysowicza, Protasego i Manasjusza. Filoteuszowi Borysowiczowi zarzucono, iż 25 sierpnia wracając $w$ stanie nietrzeźwym ze wsi Poczajów, bez przyczyny napadł na drodze pastucha Teodora i dotkliwie pobił, nanosząc liczne rany na głowie, plecach i rękach. Mnich Monasjusz miał postąpić identycznie z innym pastuchem Kondratem, gdy ów przyprowadził bydło do wodopoju. Mnichowi Protasemu zarzucono, że będąc w stanie nietrzeźwym, napadł 2 października w karczmie poczajowskiej na Ignacego Iwanicza, zadając wiele ciosów w głowę, ręce, a także wyrwał mu brodę. Woźny Paweł Żygało wnosząc powyższe oskarżenie oświadczył, że stosownie do peł-

\footnotetext{
32 ДАТО, ф. 258, оп. 3, д. 1170/4: Высписи из Кременеиких земских книг контрактов, декретов и судебных дел по земельным и денежным спорам с помещиками Бельзкими, Фирлеем и другими, Т. 1 (1644 - 46), к. 2 - 3. Skarga mnicha Monasteru Poczajowskiego Barlaama Szpraskiego do Sądu Ziemskiego w Krzemieńcu przeciwko poddanym Firleja Ignacemu Iwaniczowi i pastuchowi Kondratowi, z powodu pobicia. Левицкий, Материальы..., nr 67, s. 150 - 151. „Nie wiedat' jesli z roskazanija czyjego, albo domysłu swojego, wypadłszy i zastąpiwszy na dobrowolnej dorozie, nielitostiwie, biez dan'ja żadnoje namienszoje przyczyny, kijmi zbili, zmordowali, borodu wyrwali i ran krywych bitych, sinich kniewych na ruce prawoj i po pleczach nie mało pozadawali, z konia struciwszy (ściągnąwszy), zaledwie żywoho na ziemli lieżaczaho, odoszli”.

33 ДАТО, ф. 258, оп. 3, д. 1168, к. 213 - 14. Skarga Andrzeja Firleja skierowana przeciwko ihumenowi monasteru poczajowskiego $\mathrm{z}$ powodu otworzenia szynków w pobliżu monasteru oraz panu Samuelowi Biereżyckiemu za pobicie Teodora Kryckiego z dnia 14 lipca 1644 r.). Левицкий, материальљ..., nr 63, s. 122.
}

nionej przez niego funkcji, wezwany do zbadania sprawy, rzeczywiście widział pobitych i poranionych poddanych Firleja ${ }^{34}$. Dnia 3 stycznia 1642 r. na ręc św. Hioba i Andrzeja Firleja przysłano pismo od koronnego krawczego starosty Piotra z Żukowa Daniłowicza powiadamiające, że władze Krzemienieckie nie mogą przybyć z powodu ważnych przyczyn oraz zbliżający się sejm: „dla uważnych pryczyn i nastupajuczaho sejmu zajechaty nie mohły”. Ztego względu prowadzone dochodzenie zostało odłożone na 14 marca $1642 \mathrm{r}^{35}$.

Andrzej Firlej nie pozostawił jednak w spokoju monasteru poczajowskiego. Wysłał swego „uradnika” orlańskiego Galenzowskiego, z poleceniem zabrania drzewa monasterskiego, przygotowanego do wypalania wapna. Zebrawszy z włości orlańskich wieśniaków z wozami, zabrał ok. 200 wozów drzewa. Była to szczególnie dotkliwa krzywda nasiesiona monasterowi poczajowskiemu, który przedsięwziął budowę dużej kamiennej świątyni (wzniesionej wówczas już do połowy). Wobec jawnej grabieży św. Hiob wniósł do Sądu w Krzemieńcu skargę. W celu zbadania sprawy przybył na miejsce woźny generał Paweł Dubicki w asyście dwóch szlachciców: Pawła Kiepulińskiego i Stanisława Mokryńskiego. Dokonawszy oględzin miejsca, z którego wzięto drwa oświadczyli, iż widzieli je na podwórzu u Firleja złożone w stosy ${ }^{36}$.

W dniach 6 marca i 14 kwietnia wniesiono do grodzkich ksiąg w Krzemieńcu jeszcze dwie inne skargi przeciwko Andrzejowi Firlejowi. Pierwsza, została złożona przez św. Hioba i dotyczyła spalenia przez „uradnika” Firleja Stefana Galenzowskiego 21 lutego 1642 r. domostw wieśniaków należących do monasteru ${ }^{37}$. Natomiast druga była złożona przez byłego kapłana z Poczajowa Jakuba Zalizo przeciwko temu samemu „uradnkowi” Galenzowskiemu, który naraził go na dotkliwe straty, mianowicie zagnał całe stado koni i bydła na zasiane zbożem pole duchownego i całkowicie wydeptał, pozostawiając go bez środków do przeżycia. Następnie 25 stycznia 1642 r. wraz z dozorcą Karczewskim, Aleksandrem Pietkiewiczem, stróżem Iwanem i innymi, ponownie napadł na dom kapłana Jakuba. Nie zastawszy go w mieszkaniu, gdyż w tym czasie wyjechał z najświętszymi sakramentami do chorego, zniesławili jego żonę, pobili dzieci i przegnali służącą. Spotkawszy duchownego na drodze, powracającego od chorego, Galenzowski zaczął go obrzucać obelgami mówiąc, iż „do lesu aby iszoł sarn i zajacej na sieti gonit', zboża w humnie pańskom nabirat' a do Bogu z pospolitymi ludmi otwozit...." Usłyszawszy odpowiedź kapłana, iż do jego obowiązków należy troska o dobro wiernych: „że on powinien cerkwi pilnowat i Pana Boga za

\footnotetext{
34 Левицкий, Материалы..., nr 68, s. 151 - 152.

35 ДАТО, ф. 258, оп. 3, д. 1169, к. 3. Pismo koronnego krawczego starosty Piotra z Żukowa Daniłowicza z 3 stycznia 1942 r. na ręce ihumena poczajowskiego informujące o przełożeniu prowadzonego dochodzenia na 14 marca 1642 r. Левицкий, Материальљ..., nr 35, s. 68 - 69.

36 ДАТО, ф. 258, оп. 3, д. 1169, к. 7 - 8. Skarga ihumena monasteru poczajowskiego na Andrzeja Firleja za grabież 200 wozów drzewa (19 lutego 1642 r.). Левицкий, Материальљ.., nr 36, s. 69 - 70.

37 ДАТО, ф. 258, оп. 3, д. 1169, к. 13 - 14, 17 - 18. Skarga ihumena Poczajowskiego na Andrzeja Firleja za nasłanie starosty orlańskiego Galenzowskiego i spalenie domostw wieśniaków (25 lutego i 6 marca 1642 r.).
} 
onych ludiej chrestijanskich prosit”, Galenzowski rzucił się na niego, zadając mu liczne ciosy: „porwawszysie do powoda, wprod borodu wyrwał, w hubu piast'ju biti poczał i raskrwawił, a potom w hołowu $\mathrm{z}$ tym płazom kordom udarył, palec na prawoj ruce haniebnie stołk, że onym do tych czas nie władniet; słowa bluznirskije z ust swoich wypusczał, chotiaczy jego do ostatku ubiti..." Jakub Zalizo ostatnimi siłami wyrwał się z rąk oprawców i uciekł. Od tego czasu był zmuszony do ukrywania się przed prześladowaniami i nie pojawiania się w mieszkaniu, w którym czychał na niego Galenzowski „i gdyby jego w domu zastał, pewnie by nie żywił...”. Rzeczy kapłana Jakuba zamknął w cerkwi, a inne wyrzucił na ulicę ${ }^{38}$. Woźny generał Stanisław Poroszkiewicz oraz dwaj obecni z nim szlachcice Maciej Łasiewicz i Daniel Mondrycki potwierdzili prawdziwość wniesionych przez św. Hioba skarg ${ }^{39}$.

Po długim oczekiwaniu, 15 marca 1642 r. do Poczajowa przybył podkomorzy Daniel Jełowiecki w celu przeprowadzenia na miejscu dochodzenia w sprawie sporów ziemskich pomiędzy monasterem poczajowskim a Andrzejem Firlejem. Św. Hiob z braćmi wskazali jemu miejsce, z którego należy przeprowadzić dochodzenie w sprawie granic. Znajdowało się przy drodze prowadzącej ze wsi Poczajów, wzdłuż pańszczyźnianych pól, do wsi Dunajów. Firlej zaprotestował sugerując, iż miejsce, z którego zamierzają rozpocząć przeprowadzanie granic gruntów monasterskich znajduje się w jego posiadaniu. Mnisi natychmiast zaoponowali twierdząc, iż przyprowadzili podkomorzego na grunta będące własnością monasteru, dokładnie na miejsce, skąd pierwotnie fundatorka Anna Hojska rozpoczęła przeprowadzanie granic. Uzasadniając słuszność swych słów okazali akt fundacyjny. Podkomorzy wysłuchawszy oświadczenia obydwu stron zdecydował, aby rozpocząć dochodzenie z miejsca wskazanego przez stronę powodową. Jednocześnie zlecił woźnemu Stanisławowi Poroszkiewiczowi sporządzenie stosownego zapisu zobowiązującego obydwie strony do udziału w rozprawach. Pozwany złożył apelację do Trybunału Lubelskiego na powyższą decyzję podkomorzego, która została odrzucona. Trybunał stwierdził, iż nie naniesiono żadnego uszczerbku jego gruntom. Nieukontentowany $\mathrm{z}$ obrotu sprawy wniósł skargę na stronniczość i niesprawiedliwość sądu, na co podkomorzy odpowiedział, iż postąpił zgodnie z prawem.

Następnie odczytano skargę mnichów przeciwko Andrzejowi Firlejowi, który zostawszy po śmierci swej babki Anny Hojskiej spadkobiercą i właścicielem Poczajowa, zamiast stać się obrońcą i opiekunem monasteru poczajowskiego, sam przyczynniał mu wiele krzywd, rujnował i pustoszył nie zważając na zapis zawarty w testamencie. Wielokrotnie nakazywał swym sługom i chłopstwu niszczenie znaków granicznych, wg. których były oznaczone pola monasterskie

ДАТО, ф. 258, оп. 3, д. 1169 , к. 44. Skarga byłego kapłana poczajowskiego Jakuba Zalizo przeciwko uradnkowi Galenzowskiemu (14 kwietnia $1642 \mathrm{r}$.).

39 ДАТО, ф. 258, оп. 3, д. 1169 , к. 17 - 18. Skarga ihumena poczajowskiego na Andrzeja Firleja za nasłanie starosty Orlańskiego Galenzowskiego i spalenie domostw wieśniaków (6 marca 1642 r.). Левицкий, Материалы..., nr 37, s. 71 - 72. a także zbierał z nich plony. Podobnie postępował z lasem i sianokosami. W wyniku zaistniałej sytuacji strona powodowa przeniosła sprawę z Sądu Ziemskiego w Krzemieńcu do Sądu Podkomorskiego oraz wezwała Andrzeja Firleja do odpowiedzenia za swe czyny, zadośćuczynienia za wyżądzone szkody oraz ponownego, odtworzenia granic majątków ziemskich monasteru zgodnie $\mathrm{z}$ testamentem.

Podkomorzy, po wysłuchaniu oświadczenia obydwu stron, postanowił aby oskarżony Andrzej Firlej odpowiedział na roszczenia mnichów - powodów. Firlej nie uznał orzeczenia podkomorzego za sprawiedliwe i chciał apelować do Trybunału Lubelskiego, na co mu jednak nie zezwolono. W odpowiedzi Andrzej Firlej złożył prośbę o odroczenie rozprawy. Jednak strona powodowa wyraźnie sprzeciwiła się zsyłając się na prawo, że odroczenie w Sądzie Podkomorskim może być udzielone jedynie w dwóch przypadkach: gdy w sprawie bierze udział kilku oskarżonych wówczas jeden $\mathrm{z}$ nich może otrzymać odroczenie $\mathrm{z}$ chwilą, kiedy rozpatrywanie spraw innych zostaje odłożone oraz jeżeli pozwani sukcesorzy są niepełnoletnimi wtedy prawo przewiduje odroczenie. Prośba oskarżonego nie spełniała żadnego z przedstawionych warunków ale wyraźnie działała na szkodę strony powodowej. W tej sytuacji podkomorzy odrzucił prośbę pozwanego o odroczenie sprawy.

$\mathrm{W}$ trakcie dalszej rozprawy, oskarżony zarzucił mnichom, że bez zezwolenia archimandryty lub biskupa, któremu podlegają, nie mogą prowadzić żadnej sprawy sądowej ${ }^{40}$. Według oświadczenia Andrzeja Firleja w sprawie gruntów, na których się znajdowali, w dolinie nie było żadnych kopców (znaków granicznych). Twierdził, że sądząc z zapisu fundacyjnego, kopce w liczbie 32 powinny przechodzić nie wzdłuż wsi, jak wskazywała strona powodowa, ale pod samym monasterem w pobliżu lasu. Oskarżony zarzucił stronie powodowej, że zmyśliła jakieś zniszczone kopce, które miały się ciągnąć od doliny, przez wieś w kierunku potoku. Jego zdaniem nie było to możliwe, gdyż przy potoku znajdowały się chłopskie domostwa z ogrodami poddanych zamieszkujących to miejsce znacznie wcześniej niż założono monaster ${ }^{41}$. Wobec oświadczenia pozwanego, że monaster nie posiada prawa do procesowania się bez obecności i zezwolenia biskupa, strona powodowa powtórzyła, że zarówno przeorom rzymskokatolickich klasztorów oraz prawosławnych przysługuje prawo samodzielnego prowadzenia spraw sądowych i obrony ich przed uciskami a biskupi nie wtrącają się w ich sprawy ${ }^{42}$.

\footnotetext{
$40 \quad$ „...sami czerncy bez archimandryty albo władyki, od których dependent y bez których ich wille et holle nullum czyni, gdyż ordo ich Bazilianus sine abbate constare neguit o grunty monasterskie, a zatym y o granicy czynić ani danych akcyi swoich sine seniore ut pote abbate przez siebie samych popirać nie mogą”. ДАТО, ф. 258, оп. 3, д. 1169, к. $29-$ 30. Odpis z Ksiąg Podkomorskich powiatu krzemienieckiego w sprawie wyznaczenia granic pól monasterskich z dnia 15 marca 1642 r. Левицкий, материальь..., nr 39, s. 78.

${ }^{41}$ „A oni (tj. strona powodowa) w siebie samych pretendują sobie kopce ja kieś rozsypane, których ani possibilitas jaka pokazać się może, gdyz przyj tym potoku w siebie samym chałupu, których kilkanaście z ogrodami poddanych pozwanego własnych są dawniejsze, nizeli monastyr...”. ДАТО, ф. 258, оп. 3, д. 1169, к. 30. Левицкий, Материальь.., nr 39, s. 78. 42 „A w postępowaniu powodowie wywodzili y pokazowalisię bądź naleźnemi aktorowie od tąd, iż jako przeorowie w katolickich klasztorach,
} 
Dnia 18 marca podkomorzy wznowił przesłuchiwanie zeznań świadków. Po przesłuchaniu świadków, pełnomocnik oskarżonego Daniel Grudnicki wniósł protest na stronniczość i nieprawidłowości prowadzonego śledztwa. Twierdził, że powodowie kierując liczne skargi do sądu ziemskiego, grodzkiego a obecnie również podkomorskiego, chcą odebrać u pozwanego cały Poczajów z poddanymi, polami i sianokosami, przeprowadzając granice swych posiadłości przez wieś wzdłuż potoku, a nie obok doliny w pobliżu lasu, jak ukazano w testamencie. Według niego ziemie, o które domagają się mnisi, od dawnych czasów miały przynależeć do właścicieli Poczajowa, jeszcze przed napisaniem testamentu. W tej sytuacji Sąd Podkomorski, nie posiadał podstaw prawnych do przeprowadzania granic bazując na wytycznych strony powodowej. Ponadto, powodowie podczas prowadzenia sprawy przedstawili świadków $\mathrm{z}$ oddalonych wsi, zbyt słabo obeznanych z tą sprawą, kierując się jedynie tym, aby byli prawosławni.

Mnisi zaprotestowali dowodząc, że świadkowie to szlachta mieszkająca w bliskim sąsiedztwie z Poczajowem oraz niektórzy spośród wieśniaków w podeszłym wieku, którzy zamieszkując sąsiednie wsie są dobrze obeznani z granicami monasterskich włości. Niektórzy z nich byli nawet uczestnikami przeprowadzenia granic przez fundatorkę Annę Hojską. Następnie podkomorzy polecił, aby pozwany przedstawił swych świadków, którymi byli jego słudzy: Dawid Kopicki, Iwan Brżyski, Krzysztof Podgórski, Tomaszewski, Jeremiasz Życiński, Maciewski, Dymitr Koziński, Stanisław Tomkowicz i inni. W obliczu przedstawienia przez oskarżonego powyższych świadków, strona powodowa zaprotestowała opierając się na prawie zakazującym występowania w roli świadka sługom swego pana ${ }^{43}$. $\mathrm{W}$ rezultacie jawnego naruszenia prawa, 24 maja mnich Genadiusz w imieniu św. Hioba wniósł do Ksiąg Grodzkich skargę na Andrzeja Firleja, w której czytamy, że podczas prowadzenia przez Podkomorzego śledztwa w sprawie gruntów kasztelan bielski przedstawiał świadków, którzy byli przez niego zastraszeni, wobec czego nie składali prawdziwych zeznań ${ }^{44}$.

Firlej zaprzeczył postawionym zarzutom twierdząc, że świadkowie byli osobami w pełni uczciwymi i rzetelnymi. Niektórzy z nich jeszcze podczas życia fundatorki monasteru Hojskiej dzierżawili jej ziemię, dlatego dobrze znają granice jej posiadłości. Co się tyczy jego poddanych,

tak też y ihumenowie $\mathrm{w}$ monasterach ruskich mieszkaiące zawsze bez asystencyey biskupow y władykow kazdey krzywdy klasztoru jey z kapituła dochodzą y dochodzić mogą, a biskupi y władykowie do tego się nie wiązą...”. ДАТО, ф. 258, оп. 3, д. 1169, к. 30. Левицкий, Материаль..., nr 39, s. 78.

43 „A pokazawszy prawo pospolite o świadkach opisanę, to iest, statutu rozdziału 4, artykułu 53, ze niewolnicy, alias poddanę, tak tez sługi swiddczyć za panem nie mogą, do tegoz statutu rozdziału 9, artykułu trzeciego, ze swiadkow tylko rzymskiego albo greckiego zakonu, ktorzy spowiedz odprawiaią y Ciało Panskie przyimuią bydz maią, a inszey religiey przypuszczonę do swiadetstwa bydz nie mogą, iąko o tym prawo szyrzey świadczy...”. ДАТО, ф. 258, оп. 3, д. 1169, к. 33 - 34; Левицкий, материальк.., nr 39, s. 82.

44 ДАТО, ф. 258, оп. 3, д. 1169, к. 92. Skarga ihumena poczajowskiego przeciwko wystawianiu przez Andrzeja Firleja fałszywych świadków (24 таја 1642 r.). Левицкий, Материалы..., nr 43, s. 93 - 94. to przedstawił ludzi w podeszłym wieku, uczestniczących w wydzielaniu monasterowi darowizny w postaci gruntów ukazanych w zapisie, oraz w stawianiu znaków granicznych. Według zeznań Firleja monaster rościł nieuzasadnione pretensje niezgodne $\mathrm{z}$ zapisem fundacyjnym. W samej rzeczy, gdyby przeprowadzono granice zgodnie z żądaniami stawianymi przez powodów, to otrzymaliby oni teren o powierzchni 2 mil ukraińskich, tzn. prawie cały Poczajów wraz z jego polami, lasami i sianokosami, co nie zgadzałoby się z jakimkolwiek zapisem. Testament wyraźnie stwierdzał, że do monasteru powinno należeć 6 poddanych $\mathrm{z}$ ich zagrodami i polami: „diesiat' wołok pola w try ruki (w trzech kawałkach), po diesiati rezon w każduju ruku”. Taka ilość ziemi jest całkowicie wystarczająca do utrzymania monasteru, składającego się z 8 mnichów i 2 diakonów. Igumen, jak zakładał testament, powinien być osobą cichą, skromną, rozważną, posłuszną, kierującą się dobrem ogółu, a nie własnym bogaceniem się. Mnisi, pomimo nadanych im gruntów, powinni żyć w ubóstwie. Według Andrzeja Firleja wskazany przebieg granic miał jakoby zgadzać się z zapisem, a także z zeznaniem 80 - letniego poddanego, który wraz z fundatorką Anną Hojską ustawiał znaki graniczne.

W powyższej sytuacji powodowie przedstawili plan przeprowadzenia granic posiadłości, z którego wynikało, że zgodnie z zapisem fundatorki nadzielanie monasteru gruntami rozpoczęła od drogi zdążającej z Poczajowa w kierunku Dunajewa, gdzie postawiono 7 kopców (znaków granicznych). Musiało to więc nastąpić we wskazanej przez nich dolinie, ponieważ inna na której by postawiono 7 kopców nie istnieje. Jeżeli pozwany zarzucał nieprawidłowość przeprowadzenia granic na podstawie, że strona powodowa próbowała wytyczyć je w pobliżu potoku, o którym nie wspomina się $\mathrm{w}$ zapisie fundatorki to należy uściślić, że pięćdziesiąt lat temu, podczas ustanawiania granic monasterskich włości oraz sporządzania zapisu fundacyjnego nie istniał potok, a jedynie dolina. Koryto potoku powstało w późniejszym czasie w wyniku spływu wiosennych wód, która naniosła nie tylko ziemię, ale także liczne kamienie.

Monaster wykazał niezasadność dokonanego wyjaśnienia fragmentu tekstu zapisu mówiącego, iż w monasterze powinno znajdować się do 10 mnichów. Słowa zawarte w testamencie należało rozumieć w sensie, że w monasterze nie powinno być nigdy mniej niż 10 mnichów ${ }^{45}$. Strona powodowa przedstawiła świadków powszechnie szanowanych, znanych ze swej pobożności oraz przywiązania do prawosławia bądź katolicyzmu. Zamieszkiwali tereny położone nieopodal granicy: łosiatyńskiej - dochodzącej do samego monasteru; leduchowskiej - przylegającej do wsi Poczajów; dunajowskiej, tarażskiej i kokrewskiej. Z tego względu byli znakomicie zorientowani w przebiegu granic monasterskich. W osobach świadków pozwany przedstawił swych sług, poddanych oraz osoby niemogące występować w roli świadków.

Po wysłuchaniu zeznań świadków w sprawie granic

45 Monaster poczajowski zgodnie z zapisem jej fundatorki Anny Hojskiej powinien mieć 8 mnichów i 2 diakonów, tzn. 10 osób. Zob. В. Левицкий, К вопросу о времени основания Почаевской Лавры и о первой устроительнице ея Анне Гойской, s. 202. 
i ustawienia znaków granicznych podkomorzy postanowił, aby jeden mnich, wybrany spośród braci oraz sześciu świadków ze szlachty złożyli przysięgę, że kopce zniszczone przez Firleja były ustawione w górnym biegu potoku i że przeprowadzenie granic wg ich ustaleń nie zaszkodzi interesom pozwanego ${ }^{46}$.

Decyzja podkomorzego w sprawie spornych gruntów była korzystną dla monasteru poczajowskiego. Nie zważając na częste protesty Andrzeja Firleja podkomorzy rzetelnie i sumiennie prowadził dochodzenie. Można by było sądzić, że proces nareszcie zadośćuczyni wyrządzonym monasterowi krzywdom. Stało się jednak całkiem inaczej. W ówczesnej Rzeczypospolitej królowała pełna samowola szlachty. Codziennym zjawiskiem było naruszanie prawa. Czym bardziej wpływową była znana osobistość, tym swobodniej i nieskrępowanie odnosiła się do prawa i królewskich dekretów. W takich uwarunkowaniach decyzja podkomorzego nie przyniosła oczekiwanych rezultatów. Andrzej Firlej, jedynie dla pozoru wniósł apelację na powyższą decyzję do Trybunału Lublińskiego, ponieważ w rzeczywistości nie przestawał prześladowania monasteru.

Zachęceni sukcesem w Sądzie Podkomorskim mnisi $\mathrm{z}$ nadzieją oczekiwali na pozytywne rozstrzygnięcie pozostałych spraw. Dnia 10 kwietnia 1642 r. otworzono posiedzenie Sądu Grodzkiego w Krzemieńcu, na którym w pierwszej kolejności przystąpiono do rozpatrzenia sporów dotyczących: spalenia przez Andrzeja Firleja chałup należących do poddanych monasteru oraz grabieży drzewa z lasu monasterskiego. W charakterze świadków „do wydania prawdywoho swiedectwa" św. Hiob wezwał następujące osoby: Jurja Leduchowskiego, Pawła Andruskiego, Iwana Suzańskiego, trzech Isernickich z Leduchowa - Bazylego i dwóch Teodorów, Pawła Glibkę, Teodora Hryniewieckiego z Łosiatynia, Piotra Zająca, Bazylego i Iwana Mińkowskich i Pawła Dubińskiego ${ }^{47}$.

Pełnomocnik Firleja - Daniel Grudnicki, jak zwykle czynił możliwe przeszkody, aby przerwać lub opóźnić rozprawę. Zarzucił woźnemu Stanisławowi Poroszkiewiczowi, że nie wniósł pozwu w należytym momencie oraz bezprawnie wprowadził do protokołu stwierdzenie, iż sprawa nie podlega Sądowi Grodzkiemu, ale powinna być rozpatrywana przez Sąd Ziemski. Następnie chcąc dowieść niesłuszność strony powodowej zarzucił, że: po pierwsze grunta, na których znajdują się chłopskie chaty są własnością ich patrona - Firleja, a pozwowie roszcząc sobie prawo targaja się na cudzą własność; po drugie Hiob Zalizo nie jest ihumenem monasteru; po trzecie wszczęli sprawę sądową bez wiedzy biskupa Łuckiego ${ }^{48}$.

Sąd w Krzemieńcu skłonił się jednak w swej decyzji

\footnotetext{
46 ДАТО, ф. 258, оп. 3, д. 1169, к. 25 - 38. Odpis z Ksiąg Podkomorskich powiatu krzemienieckiego w sprawie wyznaczenia granic pól monasterskich z 15 marca 1642 r.; Левицкий, Материалы..., nr 39, s. 75 - 87. 47 Левицкий, Материалы..., nr 60, s. 87.

$48 \ldots$ „... stych racyj pierszaja, że krywdy a ni tytułu prawa do tych gruntow, skotorych pretendujut sobie krywdu nie pokazujut i pokazat nie mohut, druhaja Akcyja nienależnaja, iż otiec Żelizo nie jest ihumenom toho monastyra, i synie Asystencyja starszoho albo Jeho miłosti otca władyki Łuckoho czinyty niemożet i ot pryncypała jeho krywdy czyniat..." Tamże, nr 61, s. 89.
}

na stronę monasteru. Postanowił na miejscu zbadać stan sprawy i potwierdzić ją przysięgą dwóch mnichów. Polecił także zebrać zeznania innych świadków. Na powyższą decyzję Firlej złożył apelację do Trybunału Lubelskiego ${ }^{49}$. $\mathrm{W}$ ten sposób wszystkie sporne sprawy monasteru poczajowskiego z Andrzejem Firlejem przeszły pod decyzję wyższej instancji sądowej - Trybunału Lubelskiego.

W czasie długotrwałego sporu pomiędzy monasterem a Firlejem nie zauważamy jakiegokolwiek uczestnictwa w nim biskupa łuckiego Atanazego Puzyna. Jego pasywna postawa wzbudziła zapewne u pozwanego podejrzenie, że skierowany przeciwko niemu proces nie znalazł uznania u biskupa. Z tego względu na sądzie w Trybunale Lubelskim zasiadł nie tylko św. Hiob z kilkoma mnichami, ale również Atanazy Puzyna. Starał się on pogodzić obydwie strony naciskając, aby o spornych sprawach zdecydował sąd treciejski (należało wybrać treciejskiego sędziego z dwoma upełnomocnionymi z każdej strony). Dzięki temu 7 sierpnia 1642 r. w Lublińskim Trybunale został podpisany akt określany ówcześnie, jako „kompromliss”, z wyrażeniem zgody z obydwu stron na sąd treciejski ${ }^{50}$.

\section{Tamże, nr 61-62, s. 88 - 93.}

50 Kompromis podpisany przez Atanazego Puzyna, Andrzeja Firleja, św. Hioba, mnicha Genadiusza Daszkiewicza, Andrzeja Jełowieckiego oraz łuckiego ziemskiego pisarza Marka Gulewicza brzmiał: „My Ioan Zelazo - Ihumen, Henady Daszkiewicz, Iłarion Kozickj - Diakon, Czerncy y Zakonnicy sami przez... jmieniem Braciey swey, także czerncow y... w Cerkwie Manastyra Poczaiowskiego, z byt... Consensem Przewielebnego w Panu Bogu Iego... Aphtanazyia Puzyny Episkopa Łuckiego y ... Iako Pasterza ich zwierzchnego, y nato..., z iedney, A ja Andrzey z Dombrowice ... Kasztelan Bełski - z drugiey strony, odstąpiwszy... nalezney Jurisdictiey Woewodztw y Po... pod ten list dobrowolny zapis nasz, dobro... oddaiąc zeznawamy, y Iawno czynimy tym... dobrowolnym zapisem kazdemu, komuby o tym... nalezało: Isz my Zakonnicy, maiąc pewne... Manastyrskie z Wielmoznym Ie Moscią Panem ... także z urzędnikami y sługami Iego Miłosci, Tak... iako y Sądu Ziemskiego na conserwaty te... , iako y na przyszły Trybunał Woiewodztwa... , z obudwu stron wytoczone, których teraz... prawny nieprzypuszczaiąc, ale zycząc z ... sobie Przyiacielskiego uspokoienia y pomiar... dobrowolnym zapisem, albo compromissem... yapisuiemz się, ysz nauspokoienie tych wszyt... Gruntowych iako y inszych roznic y spraw, ... Manaserowi temu Poczaiewskiemu od... Urodzoney Paniey Anny Kozinskiego... Sędziney Ziemskiey Łuckiey, Dziedziczky... nadanego, iako tesz y do zapisu Wielmoznego Iego Miłosci Pana Radomskiego intentowanych, także o rozne krzywdy, szkody, praepeditione graniczne iako y insze pra’tensiae wszelakie Iego M. Panu Bełskiemu, sługom y Poddanym Iego Miłosc, do sądu y Urzędu Grodzkiego Ziemskiego Krzemien., Trybunału Koronnego Lubelskiego, po dzis dzien, przez nas samych zakonnikow sług y Poddanych naszych zadanych, na decisiją y ostatni rozsądek daiemy, y powinni będziemy na dzień siodmy Miesiąca Ianuarij, w Roku Przyszłym Tysiąc szesc set czteradziestym Trzecim przypadaiący. Iego Miłosc Pana Stefana Leszcza Superarbitra zwiesc, y podwoch Przyiacioł, mianowicie Zakonnicy: Urodzonych ich Miłosci Pana Michała z Kozielska Puzyne - Podsędka, a Pana Alexandra Iełowieckiego - Woyskiego Krzemienieckich, z swez strony, A ja Kasztelan Bełski, z swey strony: Urodzonych Ich Miłosciow Panow Andrzeia z Wysokiego Kaszowskiego Łowczego Wołznskiego y Andrzeia Bedonskiego, do niego przydac y wysadzic; z ktorych wysz mianowanych Przyiacioł, iesliby który naczas naznaczony nieyiechał, przeszkodą temu bydz nie może, y na tego mieysce inszego mianowac, y zwiesc wolno będzie.

Który to Iego Mosc Pan Superarbiter, ziechawszy nadzien y mieysce do wsi Poczaiowa naznaczone, stawic, a wprzod sprawy y roznice gruntowe y obiechawszy a termino a quo, ad terminum ad quem, Manaster, lasy y pola Według Funduszu ograniczyc, a potym wszytkie krzywdy y szkody decidowac y według prawa y słusznosci sądzic, y zarazem nie odwłoczną satisfactią uczynic, Rozsądkiem swym osądzic, aby conpetentem et debitum utraque pars odniosła iustitiam; y te wszytkie praetensiae, ktoreby asz 
Taki obrót spraw był wygodniejszy dla Andrzeja Firleja i skrajnie niekorzystny dla monasteru poczajowskiego. $\mathrm{Na}$ Sądzie Trybunalskim Firlej nie mógł liczyć na przychylną decyzję. Prześladowania i krzywdy wyrządzone monasterowi były zbyt oczywiste. Należy nadmienić, że posiedzenia Trybunału Lubelskiego miały odbywać się „, composciti judicu", tj. w posiedzeniu powinny uczestniczyć świeckie i duchowne osoby ponieważ sprawa dotyczyła majątku kościelnego i w ogóle religii. Pomimo wysokiego stanu i wielu znajomości Andrzejowi Firlejowi jako luteraninowi trudno było oczekiwać całkowitego uniewinnienia. Groziła mu bądź banicja - wygnanie z kraju, bądź infamia - niesława i pozbawienie opieki prawnej. Wybór treciejskiego sędzi był zatem skrajnie niepomyślnym dla monasteru. Religijna przynależność Stefana Łaszcza z Stremilcza do luteranizmu, zbiegały się z orientacją Andrzeja Firleja. Stefan Łaszcz oraz wybrani przez Firleja dwaj upełnomocnieni przyjaciele (protestanci), jednomyślnie stanęli po stronie pozwanego ${ }^{51}$. Andrzej Biedoński - rzymski katolik, wybrany początkowo przez Firleja wkrótce został oddalony a jego miejsce zajął Chorąży Czernigowski Gabriel Gulewicz z Wojucina - protestant. Drugi upełnomocniony przyjaciel - Andrzej Koszowski pomimo że był protestantem, znajdował się z nim w bliskim pokrewieństwie ${ }^{52}$. Czy monaster w tej sytuacji mógł liczyć na bezstronniczość sądu? Zawarcie „kompromissu” z wyrażeniem zgody na sąd treciejski nie

do dnia compromissu zachodzili, aby przez rozsądek tegosz Iego M. Pana superarbitra odniosły decisiją.

Aiesliby ich Mosc P. P. Przyiacieli do Iego Miłosci Pana superarbitra wysadzieni wczym discordes byli, tedy sam Iego Mosc Pan superarbiter mocen będzie definire y decidowac, według swego zdania wszytkie między Ich M. obiemy strony zachodzącą differentiae et actiones iakie kolwiek przez rozsądek ich Mosciow, albo Iego Miłosci Pana superarbitra samego wtych wszystkich sprawach uznaną będzie, zawdzięczne przyiąc, y Wiecznemi czasy my sami spotomkami, iako y następcami naszemi trzymac bez wszelakich Appelatji, po teraznieyszey decisyey powinni będziem, którego uspokoienia y Decisiey. Iego Mosc Pan superarbiter Decret swoy tych wszystkich spraw decidowanych obodwom stronam na pismie tak powinien będzie. Które uspokoienie y rozsądek Ich Miłosci Panow Przyiacioł, y Iego Miłosci Pana Superarbitra jako się wyzey pomieniło My - oboia strona - za wdzięczne przyiąwszy, wiecznemi czasy bez naruszenia trzymac, y tym się wznalazkiem Ich Mosciow kontentowac mamy y powinni będziemy, a to pod zakładem piętnastu Tysięcy złotych polskich y nagrodzeniem szkod słownie oszacowanych. O których zakład y szkody w czym kolwiek przez ktorą strone, nie dosyc się stanie temu zapisowi naszemu, forum sobie, potomkom y następcom swoim, wkazdym sądzie y Urzędzie Grodzkim Ziemskim y Trybunalskim w Woiewodztwach Kiiowskim, Brasławskim, Wołynskjm y Czerniehowskjm, także między Conserwatami Woiewodztw pomienionych... znaczamy, gdzie stanowszy, zadnych zwłok excep... dilatij, submissiey, intromissiey legatij, exemptu... pensey nie zazywaiąc, niedorosłosci lat potomkow... wymawiaiąc się, do Roku y terminu by naykrotszego... nic nie mowiąc a ni onemu contradicuiąc, na pierwszym terminie, jako nazawitym, strona niedosyc..., stronie dosyc czyniącey, zakład zapłacic y nadgrodzic od sądu nieodchodząc, sami, a po... potomky y następcy naszy, powinni będą tylekroc, ... kroc tego będzie potrzeba. Tamże, nr 64, s. $94-96$.

51 ДАТО, ф. 258, оп. 3, д. 1169, к. 177 - 178. Skarga uczestnika sądu treciejskiego Michała Puzyny na stronniczość sędzi podczas prowadzonego procesu ziemskiego pomiędzy monasterem poczajowskim a Firlejem (19 czerwca 1643 r.). Левицкий, Материалық..., nr 52, s. 106.

52 ДАТО, ф. 258, оп. 3, д. 1169, к. 167 - 169. Skarga namiestnika poczajowskiego Filoteusza Borysowicza i mnicha Genadiusza Daszkiewicza o nieprzestrzeganiu przez Andrzeja Firleja terminów rozpatrywanych spraw. Левицкий, Материалық..., nr 53, s. 108. było aktem dobrowolnym lecz „za usiłowanijem i prez wolu ludiej zacnych instancijeju", tj. pod wpływem i naciskiem biskupa łuckiego Atanazego Puzyna i prawdopodobnie bogatej ruskiej szlachty. Idąc za radą jego i innych osób na Trybunale Lubelskim zawarto pokojową umowę pomiędzy byłym kapłanem poczajowskim Jakubem Zalizo i starosta orlańskim Stefanem Galenzowskim. Jakub Zalizo wystawił mu kwitownyj zapis, iż uważa się w pełni ukontentowanym w swych krzywdach i umarza z nim postępowanie sądowe ${ }^{53}$.

Św. Hiob z bracią, znużeni przeciągającym się i uciążliwym procesem $z$ bogatym i silnym magnatem przypuszczali, że 7 sierpnia 1642 r. będzie zwrotnym punktem w stosunkach z Andrzejem Firlejem. Pokładali nadzieje w pokojowym rozstrzygnięciu licznych sporów. Przekazanie wszystkich spraw pod decyzję Sądu Treciejskiego nie tylko nie polepszyło położenia sprawy i nie doprowadziło do oczekiwanych rezultatów, ale jeszcze bardziej ją zawikłała i zaostrzyła. Szybko zrozumieli to członkowie wspólnoty monastycznej ${ }^{54}$.

Sąd Treciejski wyznaczony początkowo na 7 stycznia 1643 r., a następnie na 28 stycznia, nie odbył się z powodu: „że na tot czas Jeho miłost Pan superarbiter od Pana Boga choroboju nawieżonyj był". Stefan Łaszcz przekazał przez woźnego Pawła Żygało dwa listy skierowane do św. Hioba i Andrzeja Firleja informujące o przeniesieniu terminu sprawy na 9 marca $1643 r^{55}$. Powyższa zwłoka była celowo przedsięwzięta z poduszczenia Firleja ${ }^{56}$. Dnia 1 marca św. Hiob otrzymał list od swych przyjaciół Michała Puzyny i Aleksandra Jełowieckiego informujący, iż nie mogą się stawić ww. terminie. Pierwszy ze względu na nagły wyjazd na Pokucie, drugi z powodu choroby. Proszą, więc aby rozpatrywanie sprawy przełożono na bardziej dogodny termin ${ }^{57}$. Jednak 9 marca przybyli do Poczajowa sędzia

\section{Tamże.}

${ }^{54}$ W skardze wniesionej do Ksiąg Krzemienieckich z dnia 19 czerwca 1643 r. przez przełożonego monasteru Filoteusza Borysowicza i Genadiusza Daszkiewicza znajdujemy jego gorzkie wyznanie: „iże jeho miłost Pan Bielskij, nie respektujuczy pod nohi jeho miłost cale skłoniennuju protestantow pokoru, kotoryje (tj. mnisi) majuczy prawo i fundusz od fundatorki swojeje jeje miłost panieje Anny Kozinskoje Hojskoje sudinoje ziemskoje Łuckoje na grunty i lesy, do monastyra Poczajewskoho należaczyje, dosyt warowanyj i jassnyj majuczy i dekreta sudow ziemskich, grodskich i podkomorskich Kremianieckich, wodług prawa i słusznosti fierowanyje i onyje na approbacyju do sudu Hołownoho trybunalskoho za appellaciami na konserwaty kompozyty judycyi w roku proszłom, tysiecza szestsot czotyrdiesiat wtorom sużonyje odosłanyje, za usiłowan’jem i prez woluludiej zacnych instanczjeju, tudież też i protestantowie nie chotieczy na dalszyj czas irrytowat Jeho miłost Pana Bielskoho, jako po fundatorce i dobrodiejce swojej zapisanoho sukcessora, a dla prudszoho uspokojenia, cale się na słowo i obietnic Jeho miłost Pana Bielskoho pustili, na sud polubownyj pozwolili, lecz ich zdanie i opinia omyliła i miesto prudkoho uspokojenia w dołhije, z znisczeniem ubohich zakonnikow zaprowadiła labirynty”. ДАТО, ф. 258, оп. 3, д. 1169 Tamże, k. 167 - 169. Skarga namiestnika poczajowskiego Filoteusza Borysowicza i mnicha Genadiusza Daszkiewicza o nieprzestrzeganiu przez Andrzeja Firleja terminów rozpatrywanych spraw. Левицкий, Материалы..., nr 53, s. 107.

55 ДАТО, ф. 258, оп. 3, д. 1169, к. 105 - 6. Zawiadomienie o odłożeniu rozpatrywania sprawy na 9 marca 1643 r. (6 lutego 1643 r.). Левицкий, Материальљ..., nr 45, s. 97.

56 ДАТО, ф. 258, оп. 3, д. 1169, к. 112. Oświadczenie mnicha Genadiusza Daszkiewicza, iż ze strony ihumena poczajowskiego nie było żadnych naruszeń kompromisowego zapisu (10 marca 1643 r.). Левицкий, материальљ.., nr 47, s. 98 - 99.

57 Левицкий, Материальц..., nr 46, s. 98. 
treciejski Stefan Łaszcz z upełnomocnionymi przyjaciółmi Firleja oraz woźnym Pawłem Żygało. Zamiast stawić się od razu na sporne grunta, jak uczynił to wcześniej Podkomorzy, i rozpocząć dochodzenie w sprawie ustalenia granic zajechali uprzednio do Andrzeja Firleja w celu naradzenia się, a następnie do jego poczajowskiego folwarku. Stąd Firlej wysłał swych sług, aby oznajmili mnichom, że on nie tylko nie ma zamiaru zwrócić im spornych ziem, ale odbiera im także tą ostatnią. Nie potrzebuje również jakichkolwiek rozpraw, gdyż „gdzie jest sam dominus absolutus ( $t j$. wszechwładnym właścicielem), nie potrebujet"58.

Widząc, że nikt nie stawił się ze strony monasteru, sędzia treciejski Stefan Łaszcz wysłał woźnego Żygało w celu wezwania św. Hioba i niektórych z braci na rozprawę. Otrzymał jednak odmowną odpowiedź. W rezultacie Stefan Łaszcz wniósł do Ksiąg Krzemienieckich 11 marca skargę potwierdzoną relacją wspomnianego woźnego, iż „ich miłosti otcowie zakonniki Poczajewskije sami ani sie stawali, ani pryjatiel swoich nie stawyli", oraz że oni - sędziowie nadaremnie oczekiwali cały dzień na polu ${ }^{59}$. Skarga została wniesiona do Sądu Grodzkiego 12 marca przez sługę Firleja Macieja Kozińskiego. Oskarżała mnichów w niestawieniu się na dochodzenie przez co naruszyli kompromisowy zapis i zgodnie z nim musieli wypłacić za jego naruszenie 15 tys. złotych ${ }^{60}$. Ze swej strony św. Hiob odpowiedział dwoma skargami, w których wyjaśnia, że monaster poczajowski oczekiwał z niecierpliwością wszystkich trzech terminów. Jednak w wyniku zaistniałych okoliczności: jawnego sprzyjania sędzi treciejskiego Firlejowi, nieobecności jego upełnomocnionych rzymskiego katolika Andrzeja Biedońskiego zamienionego protestantem Andrzejem Gulewiczem oraz jawnej groźby ze strony Firleja nikt $\mathrm{z}$ braci monasteru nie mógł się stawić na Sąd Treciejski ${ }^{61}$.

W rezultacie Sąd Treciejski został przeniesiony na 16 czerwca $1643 \mathrm{r}$. Tego dnia ponownie przybyli do Poczajowa: Stefan Łaszcz, Andrzej Firlej z upełnomocnionymi osobami oraz reprezentanci monasteru. Spór w sprawie ustalenia granic ciągnął się dwa dni i zakończył się nowymi wzajemnymi oskarżeniami oraz ponownym przeniesieniem sprawy do Trybunału Lubelskiego. Sędzia treciejski wraz z upełnomocnionymi przyjaciółmi ze strony Firleja przybyli na miejsce dochodzenia z gotowym dekretem nie biorąc pod uwagę żadnych argumentów strony przeciwnej. Św. Hiob poprosił, aby za podstawę rozgraniczenia ma-

\footnotetext{
58 ДАТО, ф. 258, оп. 3, д. 1169 , к. 117 - 18. Protest ihumena poczajowskiego Jana Zalizo przeciwko działalności sędzi treciejskiego Stefana Łaszcza oraz protest Andrzeja Firleja wobec działyń mnichów poczajowskich, naruszających wg niego kompromisową ugodę (12 marca 1643 r.). Левицкий, Материальц.., nr 49, s. 100 - 101.

59 ДАТО, ф. 258, оп. 3, д. 1169, к. 114. Zawiadomienie wystosowane przez Stefana Łaszcza do Sądu Grodzkiego informujące o niestawieniu się ihumena poczajowskiego Jana Zalizo na rozprawę dnia 9 marca (11 marca 1643 r.). Левицкий, Материаль..., nr 48, s. 100.

60 ДАТО, ф. 258, оп. 3, д. 1169, к. 117 - 18. Protest Andrzeja Firleja wobec bezpodstawnego uchylenia się mnichów poczajowskich od wypełnienia kompromisowego zapisu (12 marca 1643 r.). Левицкий, Материальц.., nr 50, s. 102.

61 ДАТО, ф. 258, оп. 3, д. 1169, к. 112. Oświadczenie mnicha Genadiusza Daszkiewicza, iż ze strony ihumena poczajowskiego nie było żadnych naruszeń kompromisowego zapisu (10 marca 1643 r.). Левицкий, Материальљ..., nr 47, s. 99.
}

jątków wzięto poprzedni dekret podkomorzego, który 15 marca 1642 r. przeprowadził dochodzenie w celu ustalenia granic. Sędzia treciejski wraz z upełnomocnionymi Firleja nie chcieli słyszeć o powyższym dekrecie twierdząc, że przedstawiono w nim w niejasny sposób granice monasterskich posiadłości. Dodali, że zawarty w Lublinie 7 sierpnia 1642 r. kompromis znosi wszystkie poprzednie dekrety. Upełnomocnione osoby ze strony monasteru $\mathrm{w}$ obliczu jawnej niesprawiedliwości sędzi treciejskiego, wnieśli przeciwko niemu skargę do Ksiąg Grodzkich ${ }^{62}$.

W Trybunale Lubelskim wszystkie spory monasteru poczajowskiego z Andrzejem Firlejem zostały podzielone zgodnie z pozwami na trzynaście części: 1) o wydeptaniu na monasterskich polach zboża oraz skoszeniu i spaleniu siana; 2) o nasłaniu na ogrody monasterskie sług Firleja i zniszczeniu ogrodzenia; 3) o odebraniu monasterowi poczajowskiemu 10 włók ziemi; 4) o nie wypłacaniu przez Firleja corocznej sumy 30 kop litewskich groszy, wyznaczonej przez fundatorkę na potrzeby monasteru $z$ dochodów majątków orlańskich; 5) o zwrocie dziesięciny z gruntów majątku poczajowskiego, wstrzymywanej przez ponad 12 lat; 6) o grabieży depozytu monastrskiego (szat i utensylii liturgicznych) oraz wypłaceniu 20 tys. złotych w przypadku nie zwrócenia ich; 7) o zniszczeniu monasterskiej zagrody i spaleniu chłopskich chat; 8) o zagarnięciu kilku stosów drzew, przygotowanych do wypalania wapna oraz wypłaceniu 10 tys. kop litewskich groszy za naruszenie zapisu swego ojca kasztelana radomskiego; 9) o wypłaceniu takiej samej sumy za naruszenie powyższego zapisu wskutek zakazania mnichom pobierania wody z ujść poczajowskich, porąbania beczek i pobicia mnichów; 10) o przywłaszczeniu gruntów monasterskich, zniszczeniu znaków granicznych i innych krzywdach; 11) o postawieniu przed sąd poddanych Andrzeja Firleja: leśniczego Iwana, Iwana i Aleksandra Pitkiewiczów za pobicie przełożonego Filoteusza Borysowicza i diakona Hilariusza oraz obrazę godności kapłańskiej. Do wymienionych punktów wysuniętych przeciwko Andrzejowi Firlejowi, należy dołączyć: skargę wniesioną przez św. Hioba na Stefana Łaszcza za nieuczciwe ustosunkowanie się do monasteru w osobie sędzi treciejskiego; zlekceważenie dekretu podkomorskiego, w którym wyraźnie nakreślono granice posiadłości monasterskich; niedopuszczenie apelacji do Głównego Trybunału Lubelskiego ${ }^{63}$.

\footnotetext{
62 „Jako i Panowie kompromisare Jeho miłosti Pana Bielskoho buduczy Jewanjelikami i miestcu tomu swiatomu na imia niepokalanoje naswiatszoje Bohorodicy fundowanomu protiwnymi, a ku jawnoj krywdie i szkodie miestca toho swiatoho w sentencyjach zgodnymi, widieczy byt znacznoje ubliżen'je sprawiedliwosti i szkodu miestca toho swiatoho, za ich miłost zgodit się nie mohły”. ДАТО, ф. 258, оп. 3, д. 1169, к. 177 178. Skarga uczestnika sądu treciejskiego Michała Puzyny na stronniczość sędzi podczas prowadzonego procesu ziemskiego pomiędzy Monasterem Poczajowskim a Firlejem (19 czerwca 1643 r.). Левицкий, Материаль..., nr 52, s. 106.

63 ДАТО, ф. 258, оп. 3, д. 1169, к. 181 - 83. Zawiadomienie Stanisława Poroszkiewicza Sądowi Grodzkiemu w Krzemieńcu o wręczeniu przez niego wezwania Stefanowi Leszczowi oraz ponowienia 13 pozwów wobec Andrzeja Firleja (23 lipca 1643 r.). Левицкий, Материалью.., nr 54, s. 109 - 110. W Trybunale Lubelskim „storony obedwi powodowaja otec ihumen swoim i braci swojeje imieniem oczewisto, a pozwanaja także sama oczewisto u sudu niniesznieho stanowilisie i w toj sprawie
} 
Prawie wszystkie skargi monasteru poczajowskiego wniesione do Trybunału Lubelskiego były przez niego ponownie przekazane pod decyzję Sądu Treciejskiego, przy czym zwiększono liczbę upełnomocnionych o władze krzemienieckie w osobach sędzi Józefa Frykacza i Grzegorza Biedońskiego - pisarza. Sąd Treciejski w swym mieszanym składzie działał od 5 do 9 września 1644 r. Rozpatrywano na nim wszystkie krzywdy i spory monasteru z Andrzejem Firlejem. Rezultaty tego sądu były jednak identyczne z poprzednim. Żadna ze stron po długich mowach nie doszła do porozumienia składając swe apelacje do Trybunału Lubelskiego. Podczas tego sądu został min. poruszona sprawa zrabowania przez Firleja kościelnych utensylii. Interesującymi są argumenty i pobudki, którymi usprawiedliwiał swój postępek. Zarzucał nieprawomocność strony powodowej z następujących powodów: nie posiadają swego „starszego" (tj. ihumena) nadanego im przez dziedzica dlatego bez niego oraz bez zgody i obecności biskupa łuckiego żądania zwrotu majątku kościelnego są bezpodstawne. Na dowód okazał testament, w którym mówiono, że każdy ihumen winien być zatwierdzany przez dziedzica. Strona powodowa wbrew zapisowi, nie przyjęła przedłożonego przez niego ihumena (prawdopodobnie mnicha Józefa Baca), ale go sobie sama wybrała. Jeżeli oskarżyciele oczekują od niego zadośćuczynienia w pozostałych punktach testamentu to wydaje się zrozumiałym, że konieczne jest spełnienie również powyższego punktu, tzn. przyjęcie jego kandydata na stanowisko ihumena monasteru. Kategorycznie odrzucał kandydaturę wysuniętego na tą funkcję przez stronę powodową niejakiego Zalizo. W sytuacji gdy pozostawali bez ihumena w skrajnym wypadku wymagana jest obecność biskupa łuckiego, pod którego zwierzchnictwem jako nieunici pozostają.

Andrzej Firlej utrzymywał z uporem, że majątek cerkiewny nie został odebrany im siłą, jak utrzymują oskarżyciele, ale w celu ochrony przed częstymi najazdami tatarskimi. Zgodnie z dawnym obyczajem dziedzice zawsze zabierali na przechowanie utensylia kościelne, wydając je jedynie na nabożeństwa przy okazji większych świąt. Przy poprzednim ihumenie liczne przedmioty kościelne przepadły na skutek niedostatecznego nadzoru dlatego on jako kolator monasteru poczuł się zobowiązany do ochrony jego majątku. Za wiedzą mnichów zabrał więc przedmioty ukazane w przedstawionym sądowi rejestrze. Obecnie niektóre z zabranych przedmiotów już przekazano, a inne z dopuszczenia Bożego spłonęły w wyniku pożaru Zamku Kozińskiego i może poświadczyć przysięgą, iż niczego nie obrócił na własną korzyść ${ }^{64}$. Oświadczenie Firleja, że zabrane przez

mieży soboju kontrowentrowali”. ДАТО, ф. 258, оп. 3, д. 1169, к. 198. Postanowienie Sądu Trybunalskiego o rozpatrzeniu sporów ziemskich pomiędzy Firlejem i monasterem poczajowskim (13 czerwca 1644 r.). Левицкий, Материальь.., nr 59, s. 117.

64 „A pozwany powiedział, że terazniezsi actores nie mogą być należnemi aktorami z tey miary: iż starszego swego, to iest Ihumena, od dziedzica podanego, iako fundusz opiewa, nie maią, bez ktorego, iako starszego swego, nie mniey też to, że bez asszstencyi i’g mości oyca władyki Łuckiego czynić o wrocenie apparatow nie mogą; co funduszem probowawszy, iż każdy Ihumen ma być przez dziedzica tey maietnosci, iako przez teraznieyszego pozwanego monastera Poczaiowskiego podawany; a teraznieysi actores niego przedmioty kościelne spłonęły w Zamku Kozińskim, wywołało wątpliwości u strony powodowej. Wyraziła swoje zdziwienie, iż spaliły się rzeczy, a rejestr znajdujący się razem $\mathrm{z}$ nimi w sanduku pozostał cały?! ${ }^{65}$.

Chociaż na Sądzie Treciejskim z 5 września 1644 r. nie osiągnięto porozumienia, tym nie mniej wszystkie jego postanowienia były zatwierdzone przez Trybunał

nie zachowuią się według funduszu fundatorki swey tego Ihumena, ktorego pozwany, iako collater podaie, nie przyimuia, ale sobie gwoli sami obieraią, co nie moze być; ale się powinni we wszystkiem $z$ wolą fundatorki swey zachowac, bo iesli według funduszu dochodzą inszych krzywd, powiadaiąc, że koniecznie trzeba zapłacić, toć też in simili necessario potrzeba, aby i actores na tzm Ihumenie przestawali, co im collater podaie, a nie na tym, ktorego sobie z pośrodku siebie, mimo wolą kollatora, ustawiaią, bo iesli w insych punktach fundusz obserwuią, toć i w tym powinni obserwować... A w postępowaniu citatus dedukował to $\mathrm{z}$ pozwu originalnego i sądowi superarbitrowskiemu deklarował, iż iest pozew nieporządny, naprzod: że Ihumen podanego od dziedzica tych dobr nie maią, i pokazać nie mogą, bez ktorego asszstencyi żadną miarą pozew porządny być nie może, i lubo tam iakiegos Zeliza Ihumena kładną, tedy go pozwany za starszego nie przyznawa i onego nie przyimuie. Jesli ukażą introdukcyą od pozwanego, iesli go introdukowal na przełożenstwo, iako fundusz każe, approbacyą władyki, według zwyczaiu kanonow opisanych? A do tego lubo Ihumena nie maią, tedy przynaymniey było assistentiam oyca władyki Łuckiego, iako starszego pasterza swego, pod ktorego władzą, iako nie unici są do pozwu włożyć; $z$ tey tedy racyi prosił i domawiał się, aby sąd polubowny nieporządny pozew uznawszy, pozwanego od terminu uwolnił... brał się pozwany do przysięgi, iż tych rzeczy wszystkich, iako to powodowie w pozew swoy nakładli gwałtownie nie brał, ale według zwyczaiu dawnego, według reiestru od Ihumena na tenczas będącego te rzeczy do seguestru swego dla inkwisyi częstych tatarskich i dla tego, aby to nie gineło odebrał, bo ten zwyczay bywał, iz dziedzicowie wszędy do schowania brali, a potym na swęta wielkie, uroczyste do cerkwi dla nabożenstwa dawali; gdyż przed tym Ihumenowie wielkie szkody w apparatach czynili, i nie mało rzeczy przez niedozor gineło, zaczym teraznieyszy pozwany iako dziedzic i collator tego monastera, strzegąc tego, aby i dalsza uyma nie była, z wolą i wiadomoscią wszystkich czerncow, odebrał był, i to nie tak siłą, iako aktorowie w pozwie swoim nakładali, ale według regestru przed nami sądem polubownym produkowanego, gdzie niektore rzeczy i apparaty poodawał, a drugie z nawiedzenia Pańskiego przez ogień w zamku Kozinskim ze wszytkim zamkiem i ze wszystkim ochędostwem i zbiorem pozwanego tam w tym zamku będącemi pogorzeli, przy ktorem zgorzeniu tych apparatow pozwanemu ochędostwa samego na sto tysięcy, iesli nie więcey zgorzało; zaczym pozwany dedukowawszy to sądowi superarbitrowskiemu, prosił i domawiał się, aby był do przysięgi, iako bliższy w obwinieniu według prawa pospolitego przypuszczony, chcąc przysięgę wykonać, iz tych rzeczy według regestru produkowanego, ktory regestr na każdym terminie gotow iest pokazać, przy sobie nie ma, i na pozytek ich swoy nie obrocił,wszystkie z nawidzenia Boskiego zgorzeli, a drugie pooddawał; a druga i na te rzeczy, ktore w pozew nad regestr produkowany nakładli, że ich nigdy do seguestru swego nie brał, i teraz ich nie ma”. ДАТО, ф. 258, оп. 3, д. 1169, к. 234 - 36. Dekret Sądu Treciejskiego o rozpatrzeniu wszystkich skarg monasteru poczajowskiego przeciwko Andrzejowi Firlejowi (5 września 1644 r.). Левицкий, Материалы..., nr 64 , s. $141-142$.

65 W. Osadczy, Święta Ruś. Rozwój i oddziaływanie idei prawosławia $w$ Galicji, Lublin 2007, s. 391-393. R. Ergetowski, Poczajowska Ławra, „Wrocławskie Studia Wschodnie”, 2005, nr 9, s. 105-106. W Trybunale Lubelskim, na którym 27 czerwca 1646 r. powtórnie rozpatrywano tą sprawę postanowiono „aby pozwannyj zo dwiema swiedkami sobie w urożeniu rownymi prysiah w tuju rotu, iż on czast' tych reczej, szto kosztowniejszych ihumenowi monastyra tamosznieho, kotoryj na on czas był, oddał, niekotoryje zaś reczy prez ohień spalenyje sut', o nadto niczoho bolszej reczej cerkownych, o kotoryje recz jest', pry sobie nie zatrymał, a ni na pożytok swój obiernuł, zaczym onych oddawat' nie powinien”. ДАТО, ф. 258, оп. 3, д. 1170/4, T. I, к. 42 - 43. Postanowienie Sądu Trybunalskiego w Lublinie wzywające Andrzeja Firleja do zwrotu zagrabionego majątku monasterowi poczajowskiemu (27 czerwca 1646 r.). Левицкий, Материалы..., nr 73, s. 160. 
Lubelski. Dlatego św. Hiob i Andrzej Firlej zostali zmuszeni do zawarcia pokojowej umowy w lutym 1647 r. ${ }^{66}$ W charakterze zaproszonych przyjaciół podpisali się Wojski Włodzimierski Filon Jełowiecki, Andrzej Jełowiecki i Maciej Dederbało. W dowód zadość uczynienia monasterowi w uczynionych mu krzywdach, dnia 1 marca 1647 r. Andrzej Firlej wydał na imię św. Hioba pokwitowanie, iż wziął od niego „do schowania” 2 tysiące polskich złotych i zobowiązuje się je zwrócić 24 czerwca br. w dniu św. Jana Chrzciciela ${ }^{67}$. Pieniądze nie zostały zwrócone, a monaster poczajowski jeszcze długo procesował się za nie z następcami Firleja.

Dnia 10 grudnia 1647 r. Sąd Ziemski spotkał się po raz trzeci i ostatni w sprawie rozstrzygnięcia sporu ziemskiego, gdyż po nim jakiekolwiek procesy między zwaśnionymi stronami ustają. Budzący się nowy ruch narodowy wywołany powstaniem Bohdana Chmielnickiego, wstrząsnął podwalinami państwa. Począwszy od Żółtych Wód i Korsunia doszedł aż do Lwowa i Krakowa. Jego celem było nie

66 Dnia 28 lutego 1647 r. św. Hiob wraz z mnichami poczajowskimi Sofroniuszem Podhajeckim i Izajaszem Sokołowiczem w imieniu całej braci wręczyli Andrzejowi Firlejowi następujący zapis: „My wielebni w Bogu oycowie Ioan Zelizo ihumen monastyra Poczaiowskiego, Sophroni Podhaiecki, Izaiasz Sokołowicz ierodiakon a zakonnicy tego monastyra Poczaiowskiego sami od siebie y imieniem wszystkich braci y zakonników Poczaiowskich wiadomo czyniemy y dobrowolnie zeznawamy tym naszym listem, dobrowolnym quitowym zapisem każdemu, komu to wiedzieć będzie należało. Iż my zakonnicy, przychilając się do funduszu godney i świętey pamięci urodżoney iey ms'c paniey Anny Tychonowny Kozinskiego Iarofiowey Hoskiey sędziney ziemskiey Łuckiey o różne krzywdy i praetensie względem gruntu do monastyra należącego zachodzące actiy y różnych niemało tak do sądow ziemskiego y grodzskiego Krzemienieckich iako y trybunału Lubelskiego woiewodstw Kijowskiego, Wołynskiego, Brasławskiego y Czernihowskiego y conserwaty ich między sprawy duchowe y sąd superarbitrowski wielmożnemy iego ms'c panu Andrzeiowi Bełskiemu, dziedzicowi dóbr Orlenskich y sioła Poczaiowa zadali, które tak za decretami appellatiemi, iako y za prosecutiami w sądzie trybunalskim podniesione byli y nadeczetach remiss exparitate uotorum iako y nakazania przysiag $\mathrm{z}$ obudwuch stron nieskończone zostawały, u których za złożeniem się wielmożnych ich ms'ciąw panów przyiaciął zobopolnych, wszystkie krzywdy y praetensie między sobą zobopolnie y actie zachodzące (oprócz sprawy graniczney iego ms'c panu Bełskiemu do rozgraniczenia y o włoki należące żadaney na remissie paritatis utorum w tribunale zostałey y zawistey, w którey nas iego ms'c pan Bełzski według funduszy submitował się uspokoić y ograniczyć; a iesliby nas nie uspokoił, tedy wolne poparcie iey w sądzie należnym zostawuiemy y zostawiliśmy) od mała do wiela, na którym kolwiek punccie y decretach, az do daty y tego zapisu naszego quitowanego zostałe y zawiste - my zakonnicy Poczaiowscy wyżey pomienieni pomienionego iego m. pana Bełskiego, iż się nam sprawach wszystkich od iego ms'c satisfactia stała, tedy zwid iego ms'c pana Bełskiego wypuściwszy, uwalniamy, wyzwalamy y quituiemy, zawieraiąc drogę sobie samym, iako y po nas następującym Ihumenom Poczaiowskim y wszystkiej braci zakonnikom Poczaiowskim tak do poparcia tych spraw $\mathrm{z}$ appellatiami wytoczonych, iako y decretach trybunalskich zostałych y zawitych na wszystkie przyszłe y potomne czasy, y one wszystkie a wszystkie, które kolwiek iedno od nas zadane były actie, żadney nie wyimuiąc, ani zostawuiąc (oprócz gruntowey sprawy graniczney y wołok do niey należących), także protestatie, relatie, iquisitie, skrutinia cassuiemy aunihiluiemy y wniwecz obracamy wiecznie. I nas toś my dali ten list nasz quiowny zapis z pieczęciami y z podpisami rąk naszych także ich mościów p.p. przyiaciół naszych, od nas ustnie na to uproszonych”. ДАТО, ф. 258, оп. 3, д. 1170/4, Т. II, к. 10 - 11. Zawiadomienie ihumena poczajowskiego przed Sądem Ziemskim w Krzemieńcu o polubownym zakończeniu wszystkich sporów z Andrzejem Firlejem, z wyjątkiem ziemskich (4 marca 1647 r.). Левицкий, Материальь..., nr 75, s. 163

67 Левицкий, Материальь..., nr 76, s. 164. tylko polityczne wyzwolenie ruskiego narodu spod jarzma polskich możnowładców, ale również religijne. Uniwersał Bohdana Chmielnickiego z 28 maja 1648 r. wzywał wszystkich, którym „miła wiera błahoczestiwaja, ot polakow na uniju pretworennaja, sobiratsa na dobrych koniech i s isprawnym orużyjem nieotkładnie i stanuti mużestwienno i niebojazwienno, pry wsiemohuszczej pomoszczy Bożyjej protiw polakow, swoich hrabitielej, ozłobitielej i supostatow" ${ }^{68}$. Owo nawoływanie było usłyszane począwszy od Białej Cerkwi po Ruś Ugorską. Na Wołyniu zaczynają się tworzyć zagony kozackie. W tym czasie (1648 r.) umarł król Władysław IV, znany ze swej tolerancyjności oraz uspokojenia religijnych antagonizmów w swym państwie. Rozpoczął się okres bezkrólewia, odbijający się zawsze przykrymi następstwami w życiu państwa znajdującego się wówczas na skraju upadku.

Na Wołyniu zamarła społeczna i administracyjna działalność. Wszystkie instytucje zamknięto, a urzędnicy opuścili swe miejsca pracy. Z tego powodu monaster poczajowski nie mógł kontynuować procesów sądowych z Firlejem dotyczących spornych gruntów tym bardziej, że grodzkie i ziemskie księgi sądowe, w których znajdowały się wszelkiego rodzaju zapisy i akta znajdowały się w pełnym nieporządku. Po pomyślnym powrocie z oblężenia Zbaraża Andrzej Firlej przybył do monasteru upraszając przebaczenia win. Zmarł jednak w 1649 r. i niedane mu było wypełnić swych obietnic.

Powstanie Bohdana Chmielnickiego niepomyślnie odbiły się w dziejach monasteru poczajowskiego. Rozproszone w całym Wołyniu tatarskie i kozackie hordy paliły domostwa i mordowali Polaków i Żydów, nie oszczędzając przy tym miejscowej ludności. Ponadto niekorzystnie wpłynął fakt, że Poczajów leżał na drodze ruchów głównych sił hetmana w kierunku Beresteczka, gdzie 20 czerwca 1651 r. rozegrała się niefortunna w skutkach bitwa. Monaster poczajowski był wówczas doszczętnie zniszczony przez kozaków i tatarów. Zgodnie z doniesieniem wieśniaka Maksyma Małyszki, złożonego pod przysięgą w Sądzie Krzemienieckim w 1652 r. dowiadujemy się, że po przejściu przez Poczajów tatarów i kozaków opustoszało około 32 gospodarstw, a pozostało w nim nie więcej niż 13 zamieszkałych. Mieszkańcy po części wymarli, rozpierzchli się, zostali wymordowani, bądź zabrani do niewoli. W okolicznych wsiach: Komarówce, Komnatce, Bereżcach, Orli czy Sowczycach nie pozostała ani jedna chata ${ }^{69}$.

Z tej samej relacji dowiadujemy się, że spadkobiercą starosty sandomierskiego i kasztelana bielskiego Andrzeja Firleja właściciela majątków poczajowskich został jego bratanek Andrzej Firlej, możnowładca Smidyński. Okoliczności złożyły się tak, że siłą rzeczy spór monasteru poczajowskiego, a w szczególności św. Hioba z wpływowym

В. А Беднов, Православная Церковь в Польше и Литве (no Volumina Legum), Екатеринослав 1908, s. 299. J. Kaczmarczyk, Bohdan Chmielnicki, Wrocław-Warszawa 1988, wyd. Ossolineum, s. 82.

69 ДАТО, ф. 258, оп. 3, д. 1170/4, Т. II, к. 86. Doniesienie wieśniaka Maksyma Małyszki o naniesionych przez kozaków i tatarów szkodach w Poczajowie i pobliskich miejscowościach (28 września 1652 r.). Левицкий, материалы..., nr 91, s. 183 
magnatem był przerwany. Nie był on jednak bezcelowym. Bez względu na jawną stronniczość Sądu Treciejskiego: Stefana Łaszcza i innych wyraźnie sprzyjających Firlejowi, ostatni był zmuszony zadośćuczynić wielu krzywdom wyrządzonym mnichom. Zobowiązano go do: zwrotu przedmiotów kościelnych zagarniętych w 1623 r.; wypłacenia corocznej dziesięciny z majątków poczajowskich, zgodnie $\mathrm{z}$ zapisem fundatorki monasteru; nie wzbraniania w korzystaniu z ujść wodnych znajdujących się w Starym Poczajowie oraz uznania św. Hioba ihumenem monasteru. Nie rozwiązanym pozostał jedynie spór $\mathrm{w}$ sprawie spornych gruntów, który przeszedł na następców św. Hioba i ciągnął się przez całą II połowę XVII w.

Rozpatrując przedłużające się i uporczywe zmagania św. Hioba z Andrzejem Firlejem nie możemy pominąć szczególnie wyróżniającej się cechy jego charakteru mężnej obrony praw i interesów swego monasteru, wiary w Bożą opatrzność i zwycięstwo sprawiedliwości. W swych protestacjach (oskarżeniach) udowadniał, że możnowład- ca podnosił rękę nie na mnichów, którzy wszędzie mogą sobie znaleźć miejsce aby ćwiczyć się $\mathrm{w}$ ascezie, ale przeciwko samemu Bogu i Jego Bogurodzicy, która wybrała Górę Poczajowską na miejsce Swej obecności i orędownictwa. Był głęboko przekonany, że Matka Boża nie dopuści do całkowitego zrujnowania monasteru. Ta wiara dawała mu siły aby mężnie przeciwstawiać się poczynaniom magnata i walki do ostatniego tchu. $\mathrm{W}$ tych zmaganiach św. Hiob osobiście: jeździł na sądy, wnosił skargi do Ksiąg Krzemienieckich i Łuckich, niejednokrotnie przybywał do Trybunału Lubelskiego. Godnie reprezentował swój monaster nie tylko, jako ihumen, ale także jako człowiek głęboko uduchowiony. Zdawał sobie $\mathrm{z}$ tego sprawę również Firlej, który pomimo nieuznawania go prawomocnym ihumenem zmuszony był aby się z nim liczyć. Nie bez przyczyny za wszelką cenę starał się zrzucić św. Hioba ze stanowiska przełożonego i wprowadzić na jego miejsce swego protegowanego licząc, że wówczas miałby po swojej stronie pełne zwycięstwo.

\section{Bibliografia}

Державний архів Тернопільської області, ф. 258 (Почаевский Архив), оп. 3,

- д. 1168/2: Судебное дело с наследниками Анны ГойскойФирлеями Марновскими в связи с нарушениями ими завещзания Анны Гойской в пользу монастыря (9. III. - 10. XII. 1641)

- д. 1169: Выспись из городских Кременецких актовых книг (1642 - 1644)

- д. 1170/4: Высписи из Кременеиких земских книг контрактов, декретов и судебных дел по земельным и денежным спорам с помещиками Бельзкими, Фирлеем и другими, T. 1 (1644-46), T. 2 (1647 - 1658).

Материалы по истории Почаевской Лавры, t. 1, red. В. Левицкий, Почаев 1912.

\section{Opracowania:}

Adamczuk L. i Mironowicz A., Duchowieństwo prawosławne w X-XVIII wieku, [w:] Kościół prawosławny w Polsce. Dawniej i dziś, Warszawa 1993, s. 75 - 83.

Boniecki A., Firleje, [w:] Herbarz polski, t. 5, Warszawa 1902, s. 285-295.

Borkowski A., Patriarchaty Wschodu w dziajach Rzeczypospolitej (1583-1601), Białystok 2014.

Borkowski A., Początki monastycyzmu wołyńskiego, „Cerkovnyj Vestnik", 2014, nr 4, s. 30-63.

Chodynicki K., Kościół prawosławny a Rzeczypospolita polska. Zarys historyczny 1370 - 1632, Warszawa 1934.

Ergetowski R., Poczajowska Ławra, „Wrocławskie Studia Wschodnie", 2005, nr 9, s. 101 - 123.

Góralski Z., Urzędy i godności w dawnej Polsce, Warszawa 1983.

Hodyna T., Między królem a carem. Moskwa w oczach prawosławnych Rusinów - obywateli Rzeczypospolitej (na podstawie piśmiennictwa końca XVI - połowy XVII stulecia, Kraków 2008.

Kaczmarczyk J., Bohdan Chmielnicki, Wrocław-Warszawa 1988.

Lewickij W., K woprosu o wremieni osnowanija Poczajewskoj Lawry i o pierwoj ustroitielnice јејa Annie Gojskoj, „Волынския Епархиальные Ведомости", 1913, nr 6, s. 96-100, nr 7, s. 126-128, nr 8, s. 138-142, nr 9, s. 165-167, nr 11, s. 201-204.

Mironowicz A., Kościót prawosławny w dziejach dawnej Rzeczypospolitej, Białystok 2001.

Mironowicz A., The Activities of the Patriarch Teofanes III in the Polish-Lithuanian Commonwealth, [w:] The Orthodox Church in the Balkans and Poland. Connections and Common Tradition, Białystok 2007, s. 77-87.

Niesiecki K., Firlej, [w:] Herbarz Polski, t. 4, Lipsk 1839-1845, s. 24-41.

Osadczy W., Święta Ruś. Rozwój i oddziaływanie idei prawosławia $w$ Galicji, Lublin 2007.

Батюшков П.Н., Волынь. Исторические судьбы Юго-Западного края, СПб. 1888.

Беднов В.А, Православная Церковь в Польше и Литве (nо Volumina Legum), Екатеринослав 1908.

Грушевський М. С., Історія України-Руси, t. 7, Київ 1995.

Иванов В., Епископы древней Луиякой епархии, Почаев 1891.

Лаппо И. И. , Великое Княжество Литовское за время от заключения Люблинской Унии до смерти Стефана Батория (1569-1586): опыт исследования политического и общественного строя, t. 1, С.-Петербург 1901.

Макарий (Булгаков), митр. История Русской Церкви, t. 6, Москва 1996.

Малевич А., Древняя Жьдычинская архимандрия на Вольни, Почаев 1905. 
Орловский П.И., Участие запорожских казаков в восстановтении Иерусалимским патриархом Феобаном правоставной Западно-русской иерковной иерархии в 1620 году и Киевский иерковный собор 1629 года, „Киевская Старина”, 1905, nr 10, s. 133-141.

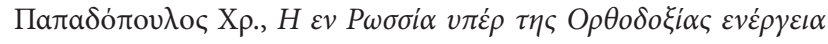

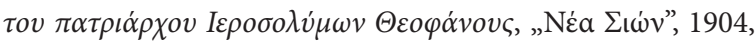
nr 1, s. 339-342.

Сендулский, Местечко Домбровица, Ровенского уезда, „Волынския Епархиальные Ведомости”, 1882, nr 9, s. 232-245.

Щеглов М., Историческая записка о Дубенской Крестовоздвиженской пустыни, „Волынския Епархиальные Ведомости”, 1884, nr 23 - 25, s. 18-31.

Rozmiar artykułu: 2,6 arkusza wydawniczego 
ISSN 1508-7719

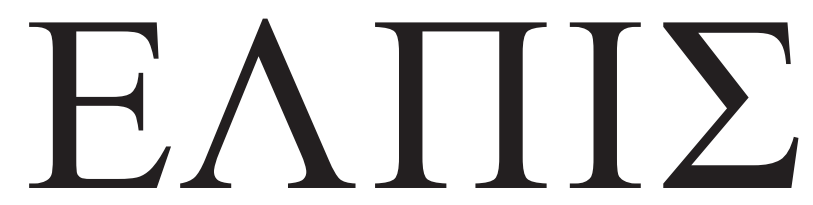

CZASOPISMO TEOLOGICZNE KATEDRY TEOLOGII PRAWOSŁAWNEJ UNIWERSYTETU W BIAŁYMSTOKU

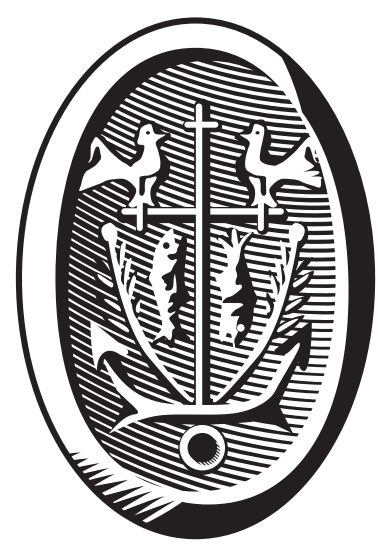

ADRES REDAKCJI

15-097 Białystok, ul. M. Skłodowskiej-Curie 14 tel. 85 745-77-80, e-mail: redakcja@elpis.edu.pl www.elpis.uwb.edu.pl 